\title{
Rifting and mafic magmatism in the Hebridean Basins
}

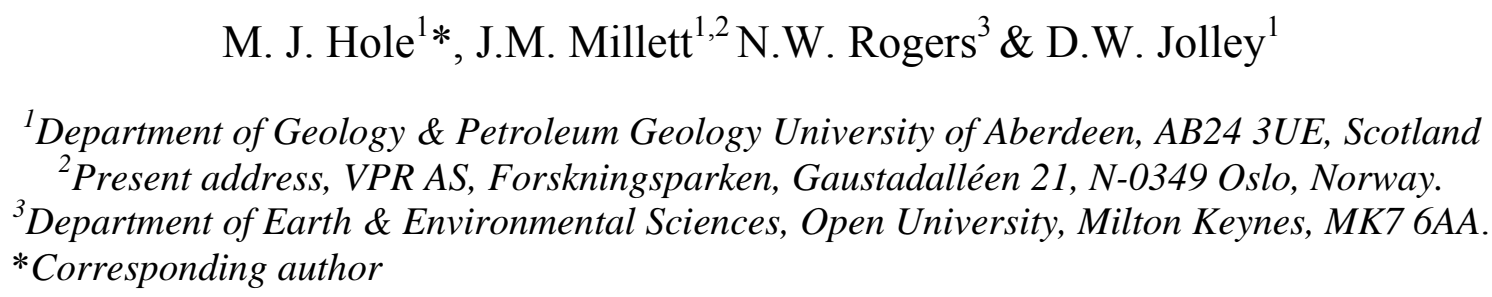

Basalt dykes from the regional dyke swarm of the British Palaeogene Igneous Province (BPIP) were emplaced parallel to structural lineaments linking onshore and offshore volcanic edifices. Basalts which underwent minimal interaction with the crust, have $\mathrm{Mg} \# 60-75, \mathrm{Nd}_{58}$ c. $8,{ }^{206} \mathrm{~Pb} /{ }^{204} \mathrm{~Pb}$ c. $17.5, \delta^{18} \mathrm{O} 5.9 \pm 0.3 \%$, and ${ }^{87} \mathrm{Sr} /{ }^{86} \mathrm{Sr}<0.7040$. Basalts with convexupwards REE profiles $\left([\mathrm{La} / \mathrm{Sm}]_{\mathrm{N}}<1 ;[\mathrm{Sm} / \mathrm{Yb}]_{\mathrm{N}}>1\right)$ were generated by limited extents of melting $(<10 \%)$ in the garnet-spinel transition of the upper mantle. Basalts with LREE depleted $\left([\mathrm{La} / \mathrm{Sm}]_{\mathrm{N}}<1\right)$ or flat REE profiles require substantial (up to $20 \%$ ) melting of spinel lherzolite. Modelling of major element compositions and olivine equilibration temperatures indicates that the mantle potential temperature was a maximum of $1530^{\circ} \mathrm{C}$ beneath the BPIP at 58-60 Ma. Magmatism occurred at the periphery of a mantle thermal anomaly (protoIceland plume; $\mathrm{T}_{\mathrm{P}} \leq 1560^{\circ} \mathrm{C}$ ) centred beneath western Greenland. The distribution of BPIP magmas was controlled by extensional tectonism driven by plate boundary forces resulting from plate reorganizations in the northern hemisphere starting at c. 62 Ma. The well-known mildly alkaline lava piles of Skye and Mull represent volcanoes on the flanks of the resulting rift system.

The mafic volcanic rocks of the British Palaeogene Igneous Province (BPIP; Fig. 1), which forms part of the North Atlantic Igneous Province (NAIP), have been the subject of detailed investigations for nearly two centuries since the early petrological pioneers first examined the igneous rocks of the province (e.g. MaCulloch 1819; Harker 1904; Bailey et al. 1924). The link between the thermal anomaly of the proto-Iceland plume and magmatism in the Hebridean basins has been much investigated and debated, particularly with respect to the 
petrogenesis of mafic magmas (e.g. Thompson 1982; Kerr et al. 1995; 1999; Fitton et al. 1997, 1998;). Hansen et al. (2009) and Nielsen et al. (2007) have argued that northern hemisphere plate reorganizations at about $62 \mathrm{Ma}$ led to stress relaxation which was responsible for precipitating continental break-up without the need to invoke a thermal mantle plume as a driving mechanism. The debate on the nature and existence of the proto-Iceland plume and the relationship of the NAIP to it, therefore remains contentious (e.g. Saunders et al. 1997; 1998; Foulger \& Anderson 2005; Mihalffy et al. 2008; Coltice et al. 2009; Foulger 2012; Howell et al. 2014).

Much of the attention in the BPIP has been focused on the evolution of volcanic edifices of the major igneous centres of Skye, Mull and Rum and their intrusive counterparts (e.g. Thompson et al. 1972, 1980, 1982, 1986; Thompson 1982; Dickin et al. 1987; Thompson \& Morrison 1988; Kerr 1995; Kerr et al. 1999). However, the offshore record of magmatism and the regional tectonic framework of the Early Palaeocene of the BPIP has been the subject of detailed geophysical surveys and geological investigations (e.g. Ritchie \& Hitchen, 1996; Hitchen et al. 1997; Dickin \& Durant 2002; Klingelhöfer et al. 2005; Archer et al. 2005; Funck et al. 2008; Hansen et al. 2009). These investigations show that specific structural lineaments link both onshore and offshore magmatic centres of the BPIP, which also reflect significant variations in crustal thickness and the depth to the Moho (Klingerhöfer et al. 2005; Funck et al. 2008). To date, the large database of geophysical, offshore geological, petrological and geochemical data has remained dispersed in the literature. In order to make a link between onshore and offshore geology and magmatism, this study aims to integrate these data. To this end, new geochemical data are presented from the regional dyke swarm of the southwest of the BPIP, which was chosen for study because it is distant from any of the major intrusive centres, and has dyke orientations that are parallel to the extrapolation of the lineaments that influence the distribution of offshore and onshore magmatic centres. Wholerock major and trace element data, mineralogical data and $\mathrm{Sr}-, \mathrm{Nd}-\mathrm{Pb}$ - and $\mathrm{O}$-isotopic 
compositions, reveal that the majority of the intrusions within the dyke swarm have escaped the major interaction with the continental crust. What little interaction that has taken place (a maximum of $6 \%$ assimilation with fractional crystallization is required) is readily identifiable, because of the large body of published data on potential crustal end-members. A number of the dykes are made of basalt with $\mathrm{Mg} \#$ in the range 65-75 which also represent some of the largest melt-fractions generated by the most extensive melting yet recorded in the BPIP. These data are used to examine temperatures of magmatic equilibration, mantle potential temperatures and the tectono-magmatic development of the North Atlantic Igneous Province.

\section{The distribution of the regional dyke swarm and its relationship to the igneous centres and of the BPIP}

The Palaeogene dyke swarm of northern Britain qualifies as a giant dyke swarm (Jolly \& Sanderson 1995; MacDonald et al. 2010) and extends from the Outer Isles in the northwest, into northern England (Fig. 1). The orientation of the dyke swarm indicates NE-SW extension occurred perpendicular to the evolving NE Atlantic continental margin (Speight et al. 1982; England, 1988; Jolly \& Sanderson 1995; Macdonald et al. 2010). The dykes can be considered to be the surface expression of linear intrusions emplaced in the lower to middle crust under the influence of regional extension (England, 1988). Cretaceous to Palaeogene offshore igneous centres of the BPIP (70-47 Ma; O’Connor et al. 2000) are also distributed along approximately NW-SE oriented structural lineaments (Fig. 1a) which are oblique to the NE-SW rifting orientation of the Rockall Trough (Ritchie \& Hitchin 1996; Dore et al. 1997; Archer et al. 2005; Nielsen et al. 2007; Ziska \& Varming 2008). The sub-parallel nature of the lineaments and the azimuth of the regional dyke swarm of the BPIP (Fig. 1), suggests a causal relationship between them. A seismic refraction survey normal to the lineaments ('Line $\mathrm{A}$ ' in Fig. 1a) reveals crust that is thinned from approximately $25 \mathrm{~km}$ to $16 \mathrm{~km}$ at three locations, forming channels in the base of the lower crust sub-parallel to the lineaments. These channels have been interpreted as continental transform faults formed by dextral shear 
(Funck et al. 2008). A seismic survey sub-parallel to one of the lineaments ('Line E' in Fig. 1a) reveals thinning of the crust from c. $32 \mathrm{~km}$ on the flanks to c. $20 \mathrm{~km}$ in the central area of the Northern Rockall Basin (Klingelhöfer et al. 2008), and the RAPIDS33 seismic line (Fig. 1a) reveals a similar structure within the Rockall Trough between latitudes $54^{\circ} \mathrm{N}$ and $56^{\circ} \mathrm{N}$ albeit with the Moho at a depth of c. $12 \mathrm{~km}$ (Kimbell et al. 2010). The Rockall Trough was the site of generation of oceanic crust during the Late Cretaceous and rifting ceased at about the time of emplacement of the seaward-dipping reflector sequences (SRDS) offshore of Hatton Bank (Nielsen et al. 2007). Thereafter, north-easterly propagating rifting occurred from Hatton Bank, along the margin of East Greenland to eventually form the Mid-Atlantic Ridge (Tate et al. 1999). The area of the northern Rockall Basin has been interpreted as the centre of one of a number of interconnected triple junctions formed during continental breakup (Hansen et al. 2009), the regional dyke swarm representing one of the arms of the triple junction which presumably failed to extend sufficiently to allow the generation of oceanic crust. Isotopic age determinations show that the majority of the magmatism in the Hebridean basins occurred over the period 63-58 Ma (Pearson et al. 1996; Hamilton et al. 1998; Archer et al. 2005) although biostratigraphical evidence suggests that magmatism may have extended to $54.5 \mathrm{Ma}$ (Bell \& Jolley 1997). The last vestige of magmatic activity in NW Scotland is represented by an Eocene monchiquite dyke in the Outer Hebrides (45.2 $\pm 0.2 \mathrm{Ma}$; Faithfull et al. 2012).

\section{The Islay-Jura-Gigha dyke swarm}

The Islay-Jura-Gigha dyke swarm (IJDS) was emplaced into Precambrian metamorphic rocks. To the west of the Loch Gruinart Fault (Fig. 1b) the Proterozoic Colonsay-West Islay Terrane comprises metasedimentary rocks and granitic gneisses (1760 Ma; Marcantonio et al. 1988) and to the east of the fault the geology is dominated by late Precambrian Dalradian Supergroup metasedimentary rocks cut by foliated epidiorites of unknown age and affinity 
(Muir et al. 1994; McAteer et al. 2010; Fig. 1b). According to Morton \& Taylor (1991), the Islay terrane is comparable in age and origin to the Rockall terrane. The IJDS has a dyke density of $<5$ intrusions $\mathrm{km}^{-1}$ and a regional extension of $<3 \%$ (see also Speight et al. 1982). The IJDS is therefore characterized by similar spacing and thicknesses of intrusions to that of the Mull dyke swarm at c. $50 \mathrm{~km}$ along strike from the intrusive centre (Jolly \& Sanderson 1995). The nearest central igneous complex to the IJDS is the offshore Blackstones Bank complex $60 \mathrm{~km}$ to the NW of Islay (Fig. 1; K-Ar whole-rock analysis indicates $58.6 \pm 1.0 \mathrm{Ma}$; Dickin \& Durant 2002) and it has been proposed that this may have been the focus for the IJDS. However, the only intrusion of any significant volume in IJDS is a minor boss of leucodolerite and teschenite which itself is the distended head of a dyke (Hole \& Morrison 1992). The azimuths of intrusions within the IJDS (320-345 ; Fig. 1b) overlaps with that for the range of fracture orientations capable of dilating within the regional stress regime according to the structural model of Jolly \& Sanderson (1995).

\section{Geochemistry basalts of the Islay-Jura dyke swarm}

The complete dataset of electron microprobe analyses of olivine, plagioclase and clinopyroxene, along with XRF major and trace element data and key locality information and analytical techniques are given in the supplementary material. Isotopic composition and major and trace element data by XRF, INAA and ICP-MS for selected samples are given in Table 1. The IJDS samples are mostly $H y$-normative $\mathrm{Si}$-saturated olivine tholeiites, but a number of $\mathrm{Ne}$-normative, Si-undersaturated alkali olivine basalts are also represented (Fig. 2). In Fig. 2a the majority of the data for the IJDS intrusions with $>8$ weight $\% \mathrm{MgO}$ scatter around the experimentally determined $0.9 \pm 0.15 \mathrm{GPa}$ cotectic for the equilibria olivine + plagioclase + clinopyroxene + natural basic liquid (Thompson 1982), and overlap with the field defined by the SMLS and MPLF. A small number of IJDS intrusions plot towards the 1atm cotectic for 
alkali olivine basalt magmas, and thus towards $\mathrm{Ne}$-normative compositions (Hole \& Morrison 1992).

Fig. 3 shows selected major and trace element data for the IJDS and igneous rocks found in the lava fields and Outer Isles dyke swarm of the BPIP. Two lineages for the BPIP lavas are evident on diagrams of $\mathrm{TiO}_{2}, \mathrm{TiO}_{2} / \mathrm{FeO}$ and $\mathrm{Zr}$ versus $\mathrm{Mg} \#$, one of which is a low $\mathrm{TiO}_{2}$, low $\mathrm{TiO}_{2} / \mathrm{FeO}^{*}$ and low $\mathrm{Zr}$, tholeiitic suite, which includes the Central Mull Formation (CMF; Kerr et al. 1999; Kent \& Fitton, 2000; Williamson \& Bell 2012), the Causeway Tholeiite Member (CTM) of Antrim (Wallace et al. 1994; Barrat \& Nesbitt, 1996) and the Preshal More tholeiites of Skye (Esson et al. 1972; Font et al. 2008). The other suite is mildly alkaline, and exhibits higher $\mathrm{TiO}_{2}$ and $\mathrm{Zr}$ concentrations at a given $\mathrm{Mg} \#$ than the $\mathrm{CTM}$ or CMF, and is exemplified by the Mull Plateau Lava Formation (MPLF) and the Skye Main Lava Series (SMLS). The IJDS data overlaps in composition with the BPIP lavas, with members of both the tholeiitic and mildly alkaline suites being represented. However, there is not a distinct separation of the two trends into low- and high-Ti groups, as is the case for the lava fields of the province. Clinopyroxene phenocrysts in the IJDS intrusions are augite $\left(\mathrm{En}_{30}\right.$ $\left.{ }_{45} \mathrm{Wo}_{40-50} \mathrm{Fs}_{14-20}\right)$ and there is no clear distinction between the tholeiitic and mildly alkaline suites on the basis of clinopyroxene compositions. Olivine phenocrysts and microphenocrysts have a compositional range of $\mathrm{Fo}_{62}-91.4$. Details of olivine thermometry will be described below.

Chondrite-normalized rare earth element (REE) profiles for IJDS are shown in Figure 4. Three distinct types of REE profile can be distinguished. The first type exhibits LREEdepletion, but with a convex-upwards REE profile $\left([\mathrm{La} / \mathrm{Yb}]_{\mathrm{N}}=0.6-1.2 ;[\mathrm{Sm} / \mathrm{Yb}]_{\mathrm{N}}>1\right)$. A second group of basalts, have LREE-enriched profiles $\left([\mathrm{La} / \mathrm{Yb}]_{\mathrm{N}}=1.6-2.5\right)$ a with $[\mathrm{La} / \mathrm{Sm}]_{\mathrm{N}}$ c. 1.0 and $[\mathrm{Sm} / \mathrm{Yb}]_{\mathrm{N}}$ in the range 1.7-2.4. Finally, a third type of REE profile is flat, to slightly LREE-depleted $\left([\mathrm{La} / \mathrm{Yb}]_{\mathrm{N}}=0.8-1.2 ;[\mathrm{Sm} / \mathrm{Yb}]_{\mathrm{N}}\right.$ 1.0-1.5), with absolute abundances of the REE of 10 to 20 times chondritic abundances. All analyzed samples of the Islay dykes 
have unradiogenic Sr-isotope compositions (0.7031-0.7041). Half of the analyzed samples plot to the left of the Geochron $\left({ }^{206} \mathrm{~Pb} /{ }^{204} \mathrm{~Pb}\right.$ ratios $\left.<17.5\right)$ in Fig. 5, and exhibit a positive correlation with $\varepsilon \mathrm{Nd}_{58}$, to a minimum of $\varepsilon \mathrm{Nd}_{58}-3.1$ at ${ }^{206} \mathrm{~Pb} /{ }^{204} \mathrm{~Pb}$ c. 16.6. This positive sloping trend includes all the samples with LREE-enriched profiles shown in Fig. 5b. Samples with convex-upward REE profiles all have ${ }^{206} \mathrm{~Pb} /{ }^{204} \mathrm{~Pb}$ in the range $17.50 \pm 0.25$ and therefore plot close to the intersection of the Geochron and NHRL. Samples with ${ }^{206} \mathrm{~Pb} /{ }^{204} \mathrm{~Pb}$ $>18.0$, are scattered around the NHRL, with $\Delta 7 / 4$ (Hart 1984) in the range -3 to $+10 . \delta^{18} \mathrm{O}$ has a limited range of $+5.8 \%$ to $+6.2 \%$ for the eight samples analyzed (Fig. $5 \mathrm{a}$ ), which also cover the full range of radiogenic isotope compositions. The IJDS basalts exhibit clear correlations between incompatible trace element ratios and isotopic compositions (Fig. 6). Chondritenormalized $\mathrm{La} / \mathrm{Sm}$ ratios $\left([\mathrm{La} / \mathrm{Sm}]_{\mathrm{N}}\right)$ and $\mathrm{La} / \mathrm{Ta}$ ratios exhibit an overall negative correlation with $\varepsilon \mathrm{Nd}_{58}$, but for $[\mathrm{La} / \mathrm{Sm}]_{\mathrm{N}}<0.8$, data are scattered. The correlation between ${ }^{206} \mathrm{~Pb} /{ }^{204} \mathrm{~Pb}$ and $\mathrm{La} / \mathrm{Ta}$ ratios is broadly negative, whilst that between ${ }^{206} \mathrm{~Pb} /{ }^{204} \mathrm{~Pb}$ ratios and $[\mathrm{La} / \mathrm{Sm}]_{\mathrm{N}}$ ratios exhibits a broadly positive correlation for samples with ratios $[\mathrm{La} / \mathrm{Sm}]<0.8$ and a more scattered distribution for samples with $[\mathrm{La} / \mathrm{Sm}]>0.8$.

\section{Magma-crust interactions}

The BPIP is a classic example of the petrological effects of magma-crust interaction and separating the effects of crustal contamination from those of mantle heterogeneity and melting processes has proven challenging. Nevertheless, it is necessary to attempt to identify those igneous rocks that have had their geochemical compositions modified by interaction with the lithosphere, so that uncontaminated samples can be identified and appropriate petrogenetic models applied to them to determine melting conditions in the upper-mantle. Since the rocks making up the continental crust in this area are of considerable antiquity, they have characteristically unradiogenic $\mathrm{Nd}$-isotope signatures $\left(\varepsilon \mathrm{Nd}_{58}<-50\right.$; Thompson et al. 1986;

Dickin et al. 1987; Fowler et al. 2003) Additionally, because primitive magmas of the BPIP 
have low REE abundances, any interaction with crust readily moves magma compositions to unradiogenic Nd-isotope compositions (e.g. SMLS and MPLF $\varepsilon \mathrm{Nd}_{58}$ as low as -30; Thompson et al. 1986; Dickin et al. 1987; Thompson \& Morrison 1988; Kerr 1995). None of the IJDS samples analyzed in this study has $\varepsilon \mathrm{Nd}_{58}<-3.0$, and the majority have positive $\varepsilon \mathrm{Nd}_{58}$, and as such none of the basalts can have undergone the same extent of crustal interaction as that which affected the most contaminated lavas of the major centres of Skye and Mull. Pb-isotope compositions of BPIP crustal rocks are more variable than Nd-isotopic compositions. The low time-integrated $\mathrm{U} / \mathrm{Pb}$ ratios of late Archean Lewisian crust means that basalts that are considered to have interacted with such crust, contain unradiogenic $\mathrm{Pb}$, plot to the left of the Geochron, and exhibit a positive correlation with between ${ }^{206} \mathrm{~Pb} /{ }^{204} \mathrm{~Pb}$ and $\varepsilon \mathrm{Nd}_{58}$ (e.g. Skye Main Lava Series, Thompson et al. 1980; 1982; 1986; Ellam \& Stuart, 2000). Lewisian granulite facies acid gneisses have considerably higher $\mathrm{Pb}$ and $\mathrm{Nd}$ abundances (about 7-10 and 20-50 ppm respectively; Rollinson, 2012) than the most primitive basalts analyzed here $(<1 \mathrm{ppm} \mathrm{Pb}$ and c. 8-10 ppm $\mathrm{Nd})$ hence isotopic shifts towards the contaminant composition occur readily, even for limited amounts of crustal interaction. Therefore, combined $\mathrm{Sr}-, \mathrm{Nd}-, \mathrm{Pb}-$ and $\mathrm{O}$-isotope systematics in BPIP lavas make it possible to place constraints on both the age and the composition of the crust which was involved in the petrogenesis of individual magmas.

\section{Isotopic constraints on magma-crust interactions}

Samples in the current data set with around 10 weight $\% \mathrm{MgO}(\mathrm{Mg} \#$ c. 58), exhibit a broad range of isotopic compositions $\left(\varepsilon \mathrm{Nd}_{58}+8\right.$ to -2$)$, and there is no apparent correlation between $\mathrm{Mg} \#$ and either ${ }^{206} \mathrm{~Pb} /{ }^{204} \mathrm{~Pb}$ or $\varepsilon \mathrm{Nd}_{58}$. This observation, combined with low values of $\delta^{18} \mathrm{O}$ $(+5.8 \%$ o to $+6.2 \%$ ) , imply crustal interaction between primitive magmas and crust prior to crystal fractionation.

Using the composition of magnesian basalt MHJ2.5 (11.1 wt \% MgO; Table 1) with $\varepsilon \mathrm{Nd}_{58}$ +7.5 as representative of an uncontaminated parental magma, AFC trajectories for $\mathrm{Pb}$ - and 
Nd-isotopic mixing, show that less than 5\% AFC involving an acid Lewisian granulite is capable of producing the entire range of $\mathrm{Pb}$ - and $\mathrm{Nd}$-isotopic compositions of the basalts with ${ }^{206} \mathrm{~Pb} /{ }^{204} \mathrm{~Pb}<17.5$ (Fig. 5). Sr-isotopes are relatively unaffected because of the unradiogenic $\mathrm{Sr}$ in the granulite contaminant. Islay basalts with ${ }^{206} \mathrm{~Pb} /{ }^{204} \mathrm{~Pb}>17.5$ exhibit a rather scattered, but overall negative, correlation between ${ }^{206} \mathrm{~Pb} /{ }^{204} \mathrm{~Pb}$ and $\varepsilon \mathrm{Nd}_{58}$, attesting to their interaction with a crustal component containing radiogenic $\mathrm{Pb}$ and unradiogenic $\mathrm{Nd}$. Supracrustal rocks of the Moine Supergroup and the Proterozoic gneisses of the Rhinns Complex of Islay, have lithologies within them that have radiogenic $\mathrm{Pb}$ compositions, with ${ }^{206} \mathrm{~Pb} /{ }^{204} \mathrm{~Pb}$ ratios up to 20 , positive $\Delta 7 / 4$ and $\delta^{18} \mathrm{O}>+8 \%$ (Morrison et al. 1985; Thompson et al. 1986; Marcantonio et al. 1988; Dickin \& Durant 2002). As a consequence, basalts that have interacted with supracrustal metasedimentary rocks exhibit a negative correlation between ${ }^{206} \mathrm{~Pb} /{ }^{204} \mathrm{~Pb}$ and $\varepsilon \mathrm{Nd}_{58}$, and have $\mathrm{Pb}$-isotopic compositions that plot above the NHRL and have $\delta^{18} \mathrm{O}>6$ (e.g. Staffa lavas; Morrison et al. 1985). An AFC mixing trajectory between MHJ2.5 as a source composition and Moine pelite (Fig. 5b), requires a conservative amount of $\mathrm{AFC}(<4 \%)$ to explain the entire $\mathrm{Pb}-\mathrm{Nd}$ array of the remainder of the Islay basalts. This limited interaction would cause shifts in $\delta^{18} \mathrm{O} \%$ o that are within the uncertainty of the analytical measurements. Modelling of Sr-isotopes for the metasedimentary rocks is more problematical, because of their large range in ${ }^{87} \mathrm{Sr} /{ }^{86} \mathrm{Sr}$ ratios in the potential contaminants. Nevertheless, Sr-isotope ratios would probably be the least affected by any contamination process because of the relatively high concentration of $\mathrm{Sr}$ in the parent magmas compared to the contaminant. However, ${ }^{87} \mathrm{Sr} /{ }^{86} \mathrm{Sr}$ ratios for these basalts are $<0.7045$, which is considerably lower than that for basalts that contain a significant upper-crustal component such as the Loch Scridain Sill Complex $\left({ }^{87} \mathrm{Sr} /{ }^{86} \mathrm{Sr}\right.$ up to 0.7105 respectively; Preston et al. 1998). Furthermore, despite the IJDS crossing two terrane boundaries (Fig. 1) there is no relationship between geographical location and contamination history of the IJDS basalts. It is also noticeable that the two contamination trends for the Islay basalts shown in Fig. 5 
232

233

234

converge at $\varepsilon \mathrm{Nd}_{58} \sim+9$ and ${ }^{206} \mathrm{~Pb} /{ }^{204} \mathrm{~Pb} \sim 17.50$. This $\mathrm{Pb}$-isotopic composition corresponds with a position close to the intersection between the Geochron and the NHRL representative of an uncontaminated parental magma. This isotopic composition is similar to that of the North Atlantic End Member (NAEM) as recognized by Ellam \& Stuart (2000).

\section{Integrated isotopic and trace element constraints on magma-crust interactions}

Fig. 7 shows La/Ta ratios plotted versus $\mathrm{Th} / \mathrm{Ta}$ ratios for BPIP mafic igneous rocks. Trace element end-member compositions for Lewisian and Moine country rocks are clearly distinguishable from one another in Figure 7 because of the higher $\mathrm{La} / \mathrm{Ta}$ for a given $\mathrm{Th} / \mathrm{Ta}$ of granulite facies Lewisian metamorphic rocks compared to Moine metasedimentary rocks (Rollinson 2012, Thompson et al. 1986; Preston et al. 1998). AFC trajectories have been calculated assuming that $\mathrm{D}_{\mathrm{Th}} \sim \mathrm{D}_{\mathrm{Ta}} \sim 0.01<\mathrm{D}_{\mathrm{La}} \sim 0.02$, and the calculated curves have been contoured for ${ }^{206} \mathrm{~Pb} /{ }^{204} \mathrm{~Pb}$ and $\varepsilon \mathrm{Nd}_{58}$, using the same end-member isotopic compositions as those shown in Fig. 5. It is clear from Fig. 7 that the most contaminated IJDS samples require only a small amount of crustal input to achieve the most extreme trace element and isotopic characteristics in the suite; a maximum of around 5\% AFC interaction with Moine metasedimentary or equivalent supra-crustal rocks, and a maximum of around $6 \% \mathrm{AFC}$ involving Lewisian granulite. The correlations between $\mathrm{Th} / \mathrm{Ta}$ and ${ }^{207} \mathrm{~Pb} /{ }^{204} \mathrm{~Pb}, \mathrm{La} / \mathrm{Ta}$ and ${ }^{206} \mathrm{~Pb} /{ }^{204} \mathrm{~Pb}$, and also that between $\varepsilon \mathrm{Nd}_{58}$ and $[\mathrm{La} / \mathrm{Sm}]_{\mathrm{N}}$ (Fig. 6), are entirely consistent with such limited estimates of crustal contamination for the IJDS compared to, for example, lavas of the SMLS which require up to $20 \%$ AFC involving Lewisian granulite. It is also noticeable on Figure 7a that IJDS Ne-normative basalts tend to be the least contaminated, implying that the tholeiitic, $H y$-normative characteristics of the majority of the basalts is an artifact of contamination and not a primary feature of the parental magma. Dacites from well 163/6-1A, which were considered by Morton et al. (1988) to be dominantly crustal melts, fall towards the end of the Moine metasedimentary contaminant melting trajectory confirming this origin. 
259

260

261

262

263

264

265

266

267

The role of the subcontinental lithospheric mantle in the petrogenesis of BPIP magmas is more difficult to establish. However, mantle xenolith suites from Permo-Carboniferous and younger magmas, suggest that the Caledonian subduction episode in the region of the BPIP resulted in the generation of subduction-enriched subcontinental mantle which now has La/Ta and $\mathrm{Th} / \mathrm{Ta}$ ratios $>20$ and $>>1$ respectively, as well as unradiogenic $\mathrm{Nd}$-isotopic compositions $\left(\varepsilon \mathrm{Nd}_{58}\right.$ as low as -22 ; Menzies \& Halliday 1988; Halliday et al. 1993). Consequently, the composition of melt derived from subduction-enriched sub-continental lithospheric mantle and that produced by the interaction between continental crust and an asthenosphere-derived melt, are difficult to distinguish. Furthermore, Downes et al. (2007) show that at certain locations in the southern areas of the BPIP (e.g. Hawk's Nib, Bute) lower crustal xenoliths have isotopic and trace element compositions that are indistinguishable from modern asthenosphere-derived melt, simply because they represent the products of young replenishments of the lower crust by basaltic magmas during continental underplating, most likely during Permo-Carboniferous rift-related magmatism (Smedley 1986; Downes et al. 2007). Nevertheless, it has been argued by a number of authors that the majority of the BPIP lavas were initially formed by melting of the asthenosphere and subsequently underwent interaction with the continental crust and/or subduction-enriched sub-continental lithospheric mantle (Fitton et al. 1997; Chambers \& Fitton 2000; Ellam \& Stuart 2000).

\section{Crystallization temperatures and mantle potential temperature}

On the basis of melting experiments on Skye lavas, which have compositions close to the DiOl divide in Fig. 2, Thompson $(1974,1982)$ defined fractionation paths for basalts from the SMLS at atmospheric pressure and $0.9 \pm 0.15 \mathrm{GPa}$, equivalent to a depth of $\sim 30 \mathrm{~km}$. Figure 2 shows that when the compositions of the IJDS basalts are projected on to the same diagram, they fall between the two cotectics, implying crystallisation and fractionation occurred at 
depths shallower than $30 \mathrm{~km}$. In addition the maximum pressure at which olivine is a liquidus phase is limited by a point on the liquidus of melting experiments on Skye lavas where four phases $(\mathrm{ol}+\mathrm{cpx}+\mathrm{opx}+\mathrm{liq})$ coexist at $\sim 1.6 \mathrm{GPa}$ (Thompson 1974). For BPIP basalts it is therefore possible to use the phase equilibria of Thompson $(1974,1982)$ and olivine geothermometry (e.g. Putirka et al. 2007) to constraint P-T conditions of olivine equilibration in olivine-bearing basalts where the Fo content of the olivine is known.

Mantle potential temperature $\left(\mathrm{T}_{\mathrm{P}}\right)$ expresses the mantle temperature projected along the solid-state adiabat to surface pressure. Crystallization temperature estimates must therefore always be lower than those of mantle potential temperature because of down-liquidus cooling of the melt during its rise into crustal magma chambers. There are a number of different methods that may be used to derive potential temperature (e.g. Falloon et al. 2007; Herzberg et al. 2007; Herzberg \& Asimow 2008; Putirka et al. 2007) some requiring knowledge of variables that are difficult to accurately determine (e.g., degree of melting and pressure of melt formation). Putirka et al. (2007) have shown that if estimates of temperature and pressure of olivine equilibration can be can be made, then these can be used to back-calculate along the adiabatic temperature gradient to yield estimates of mantle potential temperature. The model of Herzberg \& Asimow (2008) uses major element compositions of primitive magmas to make $T_{P}$ estimates without the need for knowledge of olivine compositions. Both of these models have been applied to a selection of basalts from the NIAP of appropriate composition and mineralogy, as well as to ocean ridge basalts (ORB) from the Sequeiros Fracture, which are used here as an independent control on ambient mantle $\mathrm{T}_{\mathrm{P}}$ (Herzberg \& Asimow 2008; Coogan et al. 2013).

\section{Crystallization temperature estimates}

For olivine geothermometry, an estimate of the pressure at which olivine crystallised is a requirement of models because $k_{\mathrm{D}[\mathrm{Fe}-\mathrm{Mg}]}$ for olivine and liquid is pressure dependent. The algorithm of Ulmer (1989) has been used to calculate $k_{\mathrm{D}[\mathrm{Fe}-\mathrm{Mg}]}=0.325$ at $0.9 \mathrm{GPa}$ and $\mathrm{k}_{\mathrm{D}[\mathrm{Fe}-\mathrm{Mg}]}$ 
0.335 at $1.6 \mathrm{GPa}$. Five of the IJDS samples satisfy olivine-liquid equilibrium tests using two different calculation methods (Beattie 1993; Putirka et al. 2007) which also produce comparable results (Fig. 8a). Crystallization temperatures for IJDS samples are in the range $1298-1398^{\circ} \mathrm{C}$ at $0.9 \mathrm{GPa}$ and $1325-1415^{\circ} \mathrm{C}$ at $1.6 \mathrm{GPa}$, and for lavas from the MPLF (Kerr, 1995, 1998; Kerr et al. 1999; Sobolev et al. 2007; Peate et al. 2012), crystallization temperatures are in the range $1341-1400^{\circ} \mathrm{C}$ at $1.6 \mathrm{GPa}$ and $1320-1379^{\circ} \mathrm{C}$ at $0.9 \mathrm{GPa}$ (Fig. 8a and Table 2). Overall, BPIP lavas exhibit a predictable positive correlation between Mg\# and olivine crystallization temperature, approaching a maximum of $1400^{\circ} \mathrm{C}$ at $\mathrm{Mg} \#=75$, indicating the maximum liquidus temperature of BPIP basalts (Fig. 8a). Also shown in Fig. $8 \mathrm{a}$ are olivine crystallization temperature estimates for Siquieros Fracture Zone ocean ridge basalts (Perfitt et al. 1996) and West Greenland picrites (Dale et al. 2008; Starkey et al. 2009). For the BPIP samples, crystallization temperatures are up to $100^{\circ} \mathrm{C}$ hotter than those for Siquieros ORB, but are overall cooler, by up to $100^{\circ} \mathrm{C}$, than for West Greenland picrites at comparable pressures.

\section{Mantle potential temperature estimates}

Firstly, the method of Putirka et al. (2007) has been applied to calculate $T_{P}$ from the olivine equilibration P-T estimates discussed above, and the results are given in Table 2. For BPIP magmas, estimates are from $\mathrm{T}_{\mathrm{P}}=1449-1530{ }^{\circ} \mathrm{C}$ and Siquieros Fracture Zone ORB yield $\mathrm{T}_{\mathrm{P}}=$ 1400-1433. Picrites from West Greenland (Dale et al. 2008; Starkey et al. 2009) yield 1560 to $1650^{\circ} \mathrm{C}$ using the same method (Fig. 8).

Herzberg et al. (2007) show that for primitive basalts that have crystallized only olivine (that is they fall on olivine control lines on diagrams of $\mathrm{FeO}$ and $\mathrm{CaO}$ versus $\mathrm{MgO}$ ) incremental addition or subtraction of equilibrium olivine to the measured bulk-rock composition allows the generation of a suite of potential parental melt compositions. Comparison of these with primary melt compositions determined from forward models of 
peridotite melting, allows the possible temperature of melting to be estimated. Critical to both these approaches, is that basalts must have crystallized olivine alone and not augite. Because of the polybaric fractional crystallization that characterizes the BPIP basalts (e.g. Thompson et al. 1980), augite is a common fractionating phase within the crust, as evidenced from the positive correlation between $\mathrm{Mg} \#$ and $\mathrm{CaO}$ for $\mathrm{Mg \#}$ up to about 65 (Fig. 3). Based on $\mathrm{MgO}$ - $\mathrm{FeO}-\mathrm{CaO}$ covariation, three samples from the IJDS and four samples from the MPLF (Kerr et al. 1999) are appropriate for this modelling approach, and the results of the two models are given in Table 3 and illustrated in Figure $8 \mathrm{~b}$. Primitive melts generated by the model of Herzberg \& Asimow (2008) have 15.3-18.0 weight \% $\mathrm{MgO}$ and represent melt fractions of $0.11-0.19$ (Table 3). $\mathrm{T}_{\mathrm{P}}$ estimates are $1491-1530^{\circ} \mathrm{C}$ for accumulated melt fractions. The calculation routine is successful in that it produced no evidence for augite fractionation or accumulation. Siqueiros Fracture Zone ORB (Fig. 8b) suggest ambient corrections to generate a primitive melt composition (Keiding et al. 2011; Herzberg, 2011). and MPLF basalts generated by the Herzberg \& Asimow (2008) model (Fig. 8b, Table 3). A number of workers have recognized that there are significant disparities between absolute 
2007; Herzberg 2011; Keiding et al. 2011; Coogan et al. 2014). However from these

361 discussions, a consensus emerges that for a given model, the differences between $T_{P}$ for ORB

362 picrites (representing average ambient mantle) and plume-related ocean island basalts is

363 relatively consistent at around $+100^{\circ} \mathrm{C}$ for modern Iceland and around $+200^{\circ} \mathrm{C}$ for modern

364 Hawaii (Fig. 8b). It is therefore proposed that the maximum $T_{P}$ required to generate the MPLF

365 lavas and the most mafic IJDS basalts shown in Table 3, was ambient $\mathrm{T}_{\mathrm{P}}+100$ to $+150^{\circ} \mathrm{C}$.

366 Herzberg \& Gazel (2009) derive $\mathrm{T}_{\mathrm{P}}$ for picrites from Greenland that overlap with those for the

367 MPLF and IJDS samples (Fig. 8b), but also extend to higher $T_{P}$ (West Greenland $T_{P}=1537-$

$3681561^{\circ} \mathrm{C}$; East Greenland $\left.\mathrm{T}_{\mathrm{P}}=1476-1647^{\circ} \mathrm{C}\right)$. Scarrow \& Cox $(1995)$ derived $\mathrm{T}_{\mathrm{P}}$ estimates of

$369 \quad 1390-1510^{\circ} \mathrm{C}$ for a range of SMLS lavas, although these estimates were based on primitive 370 basalt picrite composition with a uniform 15 weight $\% \mathrm{MgO}$.

371 Constraints from trace elements on the depth of melt generation

372 REE fractionation and depth and extent of melting

373 It is well-established that garnet has $\mathrm{k}_{\mathrm{D}}$ for the HREE $>>1$, but $\mathrm{k}_{\mathrm{D}}$ for the LREE $<1$ (e.g. 374 McKenzie \& O’Nions 1995; Pertermann et al. 2004; Hunt et al. 2012), and melting in the 375 presence of garnet causes significant relative LREE and HREE fractionation. In Figure 9, $376[\mathrm{La} / \mathrm{Yb}]_{\mathrm{N}}$ can be used as a proxy for extent of melting because this ratio increases with 377 decreasing extents of melting. $[\mathrm{Tb} / \mathrm{Yb}]_{\mathrm{N}}$ is sensitive to depth and thus pressure of melting, 378 with $[\mathrm{Tb} / \mathrm{Yb}]_{\mathrm{N}}$ increasing with increasing pressure of melt segregation and or source 379 enrichment (Hunt et al. 2012). Plotted in Fig. 9 are trajectories for the melting of ORB380 source mantle with garnet or spinel on the peridotite solidus. Mid-Atlantic Ridge ORB-source 381 mantle has been used in this model because trace element systematics suggest that Iceland 382 plume mantle did not become involved in magmagenesis in the BPIP until after the 383 emplacement of the major lava fields and igneous centres (Chambers \& Fitton 2000), and the 384 majority of BPIP magmas are consistent with derivation from ORB-source asthenosphere 
(Fitton et al. 1997). The starting composition for the ORB-source melting trajectory is taken from a low $[\mathrm{La} / \mathrm{Yb}]_{\mathrm{N}}$ and $[\mathrm{Tb} / \mathrm{Yb}]_{\mathrm{N}}$ ratio MAR basalt $(0.29$ and 0.99 respectively; sample DAR0080-012A-002 of Murton et al. 2002) which it has been assumed represents $20 \%$ melting of spinel lherzolite. The MAR source has then been subjected to non-modal melting with garnet-present dry melting being initiated at $3.8 \mathrm{GPa}$, equivalent to $\mathrm{T}_{\mathrm{P}} \mathrm{c} .1500^{\circ} \mathrm{C}$. The eutectic first-melt composition at $3.8 \mathrm{GPa}$ has been estimated from those given in Weng \& Presnall (2001), with a composition of $18 \%$ olivine, $50 \%$ clinopyroxene and $32 \%$ orthopyroxene. Partition coefficients for trace elements in garnet and clinopyroxene were taken from the compilation in Pertermann et al. (2004), and the remainder from McKenzie \& O’Nions (1995). In addition, trajectories for the melting of primitive mantle with garnet or spinel on the peridotite solidus are taken from Hunt et al. (2012) and are shown for comparison, along with data for picritic basalts from West Greenland (Fig 9b). Estimates of the extent of melting from trace elements are strongly model-dependent, and are particularly sensitive to the initial concentration of a trace element $\left(\mathrm{C}_{0}\right)$ in the source material. However, the overall topology of the melting curves does not vary significantly for minor variations in $\mathrm{C}_{0}$. Estimates of $F$ (extent of melting) from Fig. 9 must therefore be treated with due caution.

401

402

403

\section{REE fractionation in NAIP basalts}

It is clear from Figs. $4 \& 6$, that the IJDS basalts which exhibit LREE-enrichment $\left([\mathrm{La} / \mathrm{Sm}]_{\mathrm{N}}\right.$ $\left.>0.85 ;[\mathrm{La} / \mathrm{Yb}]_{\mathrm{N}}>1.8\right)$, do so because of interaction with continental crust. Consequently such samples have been omitted from Fig. 9a. The remaining samples all have $\varepsilon \mathrm{Nd}_{58} \geq 3$, ${ }^{206} \mathrm{~Pb} /{ }^{204} \mathrm{~Pb}$ in the range $17.4-18.2,{ }^{207} \mathrm{~Pb} /{ }^{204} \mathrm{~Pb}$ in the range $15.4-15.5$, and form a field extending from the NHRL-Geochron intersection to higher ${ }^{206} \mathrm{~Pb} /{ }^{204} \mathrm{~Pb}$ and ${ }^{207} \mathrm{~Pb} /{ }^{204} \mathrm{~Pb}$ ratios slightly above the NHRL (Fig. 5).

The Hy-normative IJDS basalts with flat REE profiles $\left([\mathrm{La} / \mathrm{Yb}]_{\mathrm{N}}=0.5-1.4\right.$ and $[\mathrm{Tb} / \mathrm{Yb}]_{\mathrm{N}}=$ 1.1-1.2) fall close to the spinel-bearing peridotite melting trajectories, but closer to that for 1$8 \%$ melting of ORB-source mantle than for that of melting of primitive mantle. In addition, 
the Herzberg \& Asimow (2008) model indicates that sample MHI2.10 which has a flat REE profile (Fig. 4) was generated in equilibrium with a spinel lherzolite residue (Table 3), and represents a melt fraction of 0.18. Two samples with convex-upwards REE profiles (MHI9.3 and MHI9.7; $[\mathrm{La} / \mathrm{Yb}]_{\mathrm{N}}$ c. 0.7 and $[\mathrm{Tb} / \mathrm{Yb}]_{\mathrm{N}}$ c. 0.4$)$ are displaced to higher $[\mathrm{Tb} / \mathrm{Yb}]_{\mathrm{N}}$ ratios for a given $[\mathrm{La} / \mathrm{Yb}]_{\mathrm{N}}$ ratio than those with flat REE profiles, suggesting that they were formed by moderate extents of melting (up to $10 \%$ ) of ORB-source mantle with garnet on the solidus. According to the Herzberg \& Asimow (2008) model, MHI9.7 was generated in equilibrium with a harzburgite residue and represents a melt fraction of 0.19 . The remainder of the data for the IJDS basalts fall between the spinel and garnet melting trajectories, implying that they were derived by melting in the region of the spinel-garnet transition of the upper mantle. Data for the Preshal More tholeiites and late stage cone-sheets of Skye (Esson et al. 1975; Bell et al. 1994; Font et al. 2008), and the most incompatible trace element depleted lava from the Causeway Tholeiite Member of Antrim (sample AM11 of Barrat \& Nesbitt 1996) also fall close to the spinel-only melting trajectory. Conversely, SMLS lavas with $[\mathrm{Tb} / \mathrm{Yb}]_{\mathrm{N}}>$ 1.8 require limited extents of melting, perhaps $<5 \%$, with garnet on the dry peridotite solidus. The remaining BPIP basalts, including the MPLF, occupy the space between the garnet and spinel melting curves suggesting melt generation in the region of the garnet-spinel transition of the upper-mantle (Fig. 9b). The Herzberg \& Asimow (2008) model indicates that at least some MPLF lavas were generated in equilibrium with a garnet-lherzolite residue (Table 3) and represent melt fractions between 0.10 and 0.15 , although REE data are not available for the MPLF samples shown in Table 3. Picrites from Baffin Island (Dale et al. 2008) have compositions that are consistent with melting with spinel on the dry peridotite solidus (Fig. 9b). Most of the Disko Island picrites (Lightfoot et al. 1997; Larsen \& Pedersen 2000) apparently require melting with garnet \pm spinel on the peridotite solidus or are derived from a more enriched, higher $[\mathrm{Tb} / \mathrm{Yb}]_{\mathrm{N}}$ and $[\mathrm{La} / \mathrm{Yb}]_{\mathrm{N}}$ ratio mantle source than the BPIP basalts. 
Since garnet alone is on the dry solidus only for $T_{P} \geq 1430^{\circ} \mathrm{C}$ (Fig. 10), then to achieve any melting solely in the garnet stability field of the mantle requires temperatures in excess of this. Major element modelling of the IJDS and MPLF basalts (Table 3) suggests maximum $\mathrm{T}_{\mathrm{P}}$ of c. $1530^{\circ} \mathrm{C}$. At this temperature, the maximum amount of melting in the presence of garnet alone would be around $10 \%$, assuming melt generation at a rate of approximately $10 \%$ $\mathrm{GPa}^{-1}$ (Fig. 10). Melt fractions representing more than $10 \%$ melting would be formed initially with both spinel and garnet on the solidus in the pressure range 3.1-2.9 GPa, and latterly with spinel alone on the solidus for $<2.9 \mathrm{GPa}$ (Fig. 10). IJDS basalts with convex-upwards REE profiles, which require melting in the presence of garnet \pm spinel on the dry solidus, are therefore consistent with melting of upper mantle with $\mathrm{T}_{\mathrm{P}} \mathrm{c} \cdot 1500^{\circ} \mathrm{C}$ (Table 3) as long as decompression to a pressure lower than that for the garnet-spinel transition was prevented. If $\mathrm{T}_{\mathrm{P}}$ was c. $1450^{\circ} \mathrm{C}$, the maximum melt fraction that could be produced with garnet alone on the solidus would be reduced to approximately one quarter of that for $1530^{\circ} \mathrm{C}$. Isotopically depleted members of the SMLS which have $[\mathrm{Tb} / \mathrm{Yb}]_{\mathrm{N}}>1.9$ require limited extents of melting in equilibrium with a garnet-bearing source. This would therefore be achievable at $T_{P} c$. $1450^{\circ} \mathrm{C}$ again assuming decompression to a pressure lower than that for garnet-only melting was prevented. The most extensive $(>10 \%)$, spinel-present melting, required by the IJDS basalts and other BPIP basalts with flat REE profiles, would only be achievable if decompression into the spinel-only stability field of the upper-mantle was permitted, and may require $\mathrm{T}_{\mathrm{P}}>1500^{\circ} \mathrm{C}$.

\section{Crustal thickness and melt migration}

The seismic refraction profiles in Fig. 1 show that in the region of the Northern Rockall Basin the Moho decreases in depth from c. $30 \mathrm{~km}$ to c. $16 \mathrm{~km}$. If it is assumed that shallowing of the Moho is proportional to local thinning of the lithosphere, then extension in the Northern Rockall Basin would have thinned the base of the lithosphere from 75 to about $60 \mathrm{~km}$, the 
462

463

464

465

466

467

468

469

470

471

472

473

474

475

476

477

478

479

480

481

482

483

484

485

486

487

former of which is the lithospheric thickness estimate of Kerr et al. (1999) for the lithosphere beneath the MPLF. This thinning would have allowed a maximum extent of melting of $\mathrm{c}$. $23 \%$ for $\mathrm{T}_{\mathrm{P}} 1530^{\circ} \mathrm{C}$ (Fig. 9), with c. $11 \%$ of melting taking place in the presence of spinel alone. This would result in the production of melts with a spinel lherzolite dominated, flat REE profile, which is in agreement with both the major and trace element models presented above (Table 3; Fig. 8). For the estimated pre-stretching thickness of the lithosphere beneath the region $\left(\right.$ c. $75 \mathrm{~km}$ ), and for $\mathrm{T}_{\mathrm{P}}=1530^{\circ} \mathrm{C}$, a maximum of approximately $18 \%$ melting would be possible, with $9 \%$ of the melting occurring in the presence of spinel alone. Consequently, beneath a $75 \mathrm{~km}$ thickness of lithosphere, convex-upward or LREE-enriched REE profiles might be expected. Variations in LREE-enrichment seen in basalts in the region, may thus be the result of melt generation beneath regions of different lithospheric thickness, which has also been proposed by other workers (e.g. Thompson 1982; Scarrow \& Cox, 1995; Kerr et al. 1999; Scarrow et al. 2000).

However, there is no evidence of significant crustal attenuation in the region of the IJDS. It would be expected that the basalts emplaced into the thickest, least stretched lithosphere would record the highest pressures of melt segregation and thus have the most marked garnet melting signature. This is not the case. As well as basalts of the IJDS, a significant proportion of the intrusions in the Outer Isles dyke swarm, the cone sheets of Skye and Antrim plateau basalts, represent large melt fractions emplaced outside the areas of maximum crustal stretching (Kent \& Fitton 2000). It seems likely therefore, that the precursor magmas of these large melt-fractions were generated in an area of significant crustal stretching (e.g. northern Rockall Basin), and that dilated fractures facilitated lateral magma transport to the southeast, and subsequent emplacement of the magmas and their crystallization at shallow crustal levels. Evidence for the transport of BPIP magmas over distances exceeding $600 \mathrm{~km}$ has been documented by Macdonald et al. (2010), with individual dykes of MPLF-type magmas being traced into the southern North Sea. Therefore, there is a structural framework that can 
adequately account for the distribution of large melt-fractions in the regional dyke swarms and the onshore and offshore magmatic centres of the BPIP, without the need for significant crustal stretching precisely at the positions of their emplacement.

The $\mathrm{T}_{\mathrm{P}}$ estimates from melt inclusions within the MPLF (Fig. 8) are $1290-1440^{\circ} \mathrm{C}$, and the whole-rock geochemistry of these samples show that they are LREE-enriched. Two of these samples have $\varepsilon \mathrm{Nd}_{58}$ 2.0-2.4 and $[\mathrm{La} / \mathrm{Yb}]_{\mathrm{N}}$ and $[\mathrm{Tb} / \mathrm{Yb}]_{\mathrm{N}}$ of 2.8 and 1.8 respectively (Peate $e t$ al. 2012) suggesting $[\mathrm{La} / \mathrm{Yb}]_{\mathrm{N}}$ has not been significantly increased as a result of crustal interaction. Consequently, according to Fig. 9, these samples require generation with garnet on the dry peridotite solidus. Lavas of the SMLS, like the MPLF, are characterized by mildly alkaline LREE-enriched compositions (Figs $3 \&$ 8). Fig. 10 shows that for $\mathrm{T}_{\mathrm{P}}=1440^{\circ} \mathrm{C}$ and a lithospheric thickness of $75 \mathrm{~km}$, the melting interval is limited to the range 3.1-2.3 GPa with a maximum extent of melting of c. $8 \%$, with $\leq 2 \%$ melt being generated with garnet alone on the dry peridotite solidus. $\mathrm{T}_{\mathrm{P}}$ estimates from melt inclusions made herein $\left(1290-1440^{\circ} \mathrm{C}\right)$, and the $\mathrm{T}_{\mathrm{P}}$ estimates of Scarrow \& Cox (1995) for SMLS lavas $\left(1390-1510^{\circ}\right)$ suggest that at least some SMLS and MPLF lavas were generated at $T_{P} \leq 1450^{\circ} \mathrm{C}$. Localized variations in $T_{P}$, be they spatial or temporal, cannot therefore be ruled out as a potential influence on the geochemical composition of BPIP basalts.

\section{Discussion}

Magma-crust interactions and magmatic plumbing.

Fowler et al. (2004) proposed an Energy-Constrained Recharge, Assimilation and Fractional Crystallization (EC-RAFC) model for the contamination history of the SMLS, and proposed a magma transport system in which magma batches are stored initially at lower-crustal levels, where they undergo EC-RAFC evolution. The EC-RAFC models used as a starting composition a mafic magma with a liquidus temperature of $1400^{\circ} \mathrm{C}$, and required up to 6 episodes of magma recharge, with an overall temperature drop of c. $130^{\circ} \mathrm{C}$ during 
contamination (Fowler et al. 2004). The model was capable of producing the entire range of $\mathrm{Pb}$ - and Sr-isotopic compositions i.e ${ }^{206} \mathrm{~Pb} /{ }^{204} \mathrm{~Pb}=17.25-14.50$ and ${ }^{87} \mathrm{Sr}^{86} \mathrm{Sr}_{58}=0.7030$ 0.7040 for the SMLS. In general, Fowler et al. (2004) noted that lower-crustal granulite is the contaminant for early-formed magmas and upper-crustal metasedimentary rocks act as the contaminant for many of the late-stage magmas. It is interesting to note that the basalts shown in Fig. 7, which show evidence of interaction with a metasedimentary contaminant, (e.g. Causeway Tholeiite Member and Staffa Lava Formation), are of the tholeiitic lineage (Fig. 3), were all emplaced as ponded lava flows into fault controlled basins (Lyle, 2000; Williamson \& Bell 2012), and all exhibit evidence of evolution along the 1 atm cotectic in Fig. 2. It has not been possible to make any estimates, directly, for $\mathrm{T}_{\mathrm{P}}$ of these magmas, largely because of their extreme contamination history, but the implication here is that these basalts were emplaced during a period of extensional tectonism. This contrasts with the majority of the SMLS and MPLF lavas which are mildly alkaline (Fig. 3) and require predominantly lower-crustal contaminant with material such as Lewisian granulite facies metamorphic rocks (Fig. 7). Consequently, it seems that within the Hebridean basins, periods of localized extensional tectonics exercised a significant control on magmatic plumbing, which in turn influenced the contamination history of individual batches of magma.

The thermal influence of the Iceland Plume on magmatism in the BPIP

The picrites of West Greenland, which are considered to be synchronous with the earlier periods of magmatism in the BPIP (c. 58-60 Ma; Pearson et al. 1996; Hamilton et al. 1998), require $\mathrm{T}_{\mathrm{P}}$ of up to $1581^{\circ} \mathrm{C}$, which is more than $50^{\circ} \mathrm{C}$ higher than that for the highest $\mathrm{T}_{\mathrm{P}} \mathrm{BPIP}$ magmas calculated by the same methods (Fig. 8). In the case of West Greenland, such temperatures could have been achieved if melting took place over a plume-head with $T_{P}=$ $1570^{\circ} \mathrm{C}$ located beneath West Greenland at c. 60 Ma. This is consistent with the proposed positions of the proto-Iceland plume at that time (e.g. Lawver \& Müller 1994; Fitton et al. 1997). In addition, the high ${ }^{3} \mathrm{He} /{ }^{4} \mathrm{He}$ of West Greenland basalts, requires a contribution from 
plume mantle to these mafic magmas (e.g. Dale et al. 2009; Stuart et al. 2000). However, for

540 a plume head of $1000 \mathrm{~km}$ diameter, the BPIP would be outside the influence of the thermal

541 anomaly at c. $60 \mathrm{Ma}$ (Fig. 1). Alternative plume positions, such as those proposed by

542 Mihalffy et al. (2007), place the plume-head further to the east at $60 \mathrm{Ma}$, and in this case, the

543 BPIP would be narrowly within the influence of a $1000 \mathrm{~km}$ diameter plume head (Fig. 1).

544 Howell et al. (2014) showed that for ambient $\mathrm{T}_{\mathrm{P}}=1338^{\circ} \mathrm{C}$, and a proto-Iceland plume with $\mathrm{T}_{\mathrm{P}}$

$545=1488^{\circ} \mathrm{C}$ (ambient $\left.+150^{\circ} \mathrm{C}\right)$, a thermal anomaly of $\geq 55^{\circ} \mathrm{C}\left(1393^{\circ} \mathrm{C}\right)$ would extend to 1000

$546 \mathrm{~km}$ from the plume head position. If the plume was hotter, at $\mathrm{T}_{\mathrm{P}}=1550^{\circ} \mathrm{C}$, then it may have

547 been possible to produce a thermal anomaly of ambient mantle $+100^{\circ} \mathrm{C}$ (absolute $\mathrm{T}_{\mathrm{P}}$ of

$\left.5481538^{\circ} \mathrm{C}\right) 1000 \mathrm{~km}$ from the plume centre, assuming the plume position of Mihalffy et al.

549 (2007). Like the West Greenland picrites, some BPIP magmas have anomalously high

$550{ }^{3} \mathrm{He} /{ }^{4} \mathrm{He}$, which also suggests a plume influence on magmatism (Stuart et al. 2000).

551 Consequently, a mantle plume-head with $\mathrm{T}_{\mathrm{P}} \geq 1550^{\circ} \mathrm{C}$ located beneath central Greenland,

552 with a diameter of influence of c. $1000 \mathrm{~km}$, could satisfy the temperature conditions for both

553 the West Greenland picrites and BPIP magmas described here, and also provide a source for

554 high ${ }^{3} \mathrm{He} /{ }^{4} \mathrm{He}$. If the required thermal anomaly was indeed located beneath West or central

555 Greenland at 58-60 Ma, then the reasons as to why magmatism should be concentrated on the

556 very periphery of the plume i.e. in the BPIP, will now be examined.

557 Tectonic controls on the distribution of magmatism in the NAIP.

558 Nielsen et al. (2007) argued that an abrupt change from contractional intra-plate deformation

559 to stress-relaxation in the adjacent European continent produced sufficient pre-rupture

560 tectonic stress to precipitate continental break-up in the North Atlantic, without the need to

561 invoke a thermal mantle plume as a driving mechanism. The data presented herein, along with

562 those of Herzberg \& Gazel (2009), do not support a solely passive rifting model for

563 magmatism in the NAIP. Nevertheless, the apparent geometry of the main igneous regions of

564 the BPIP shows similarities with trends of the embryonic stages of continental rifting regimes, 
565

consisting of numerous interconnected triple junctions (Archer et al. 2005; Hansen et al. 2009). It is one of these triple junctions which has at its focus the Northern Rockall Basin, the south-easterly arm of the triple junction being parallel to the regional dyke swarm (Fig. 1a); the triple junction also coincides with a region of localized, Early Palaeogene transient uplift (Hansen et al. 2009). In addition, the CTM and SLF appear to be related to syn-magmatic normal faulting and graben formation (Lyle 2000; Williamson \& Bell, 2012) illustrating the importance of extensional tectonism in the region.

The present-day depth to the Moho beneath Baffin Bay is c. $12 \mathrm{~km}$ (Fig. 11) and beneath the Rockall Trough c. $18 \mathrm{~km}$ (Artemieva \& Thybo 2013). Separating these two areas of stretched lithosphere is the Archean craton of Greenland with a present-day depth to the Moho of around $40 \mathrm{~km}$. Reconstructing the depth to the Moho at pre-Chron 24 time, (Fig. 11) before extension along the East Greenland margin took place, reveals two thinned areas of lithosphere, one beneath the Rockall Trough and the other the Labrador Sea, separated by the Greenland keel of lithosphere. Inevitably, magmatism would be concentrated in areas of thinnest lithosphere, and so at c. 62-58 Ma, the magmatic foci were along the opening Labrador trough in the West, and the Rockall Trough, through the Faroe-Shetland Basin, terminating in the Vøring Basin to the northeast. The small, but clearly identifiable, offshore igneous centres along the lineament from the Rockall Trough to the Vøring Basin (e.g. Archer et al. 2005; Jolley \& Bell 2002a, b) encourages the hypothesis that these represent rift-flank volcanoes formed during initial rifting. The mildly alkaline magmatism that characterizes the SMLS and MPLF, which in most cases requires melt-derivation from a garnet-bearing source (Fig.8; Table 3), and frequently involves interaction with lower-crustal granulite facies metamorphic rocks, suggests that these volcanic systems developed above lithosphere of c. 75 km thickness (Kerr et al. 1999), and therefore on the flanks of the rift that formed during the plate reorganizations described by Neilsen et al. (2007). The larger melt-fractions characterizing the IJDS, the CTM and the Preshal More basalts, all of which require a spinel- 
591 bearing source (Fig. 8), would have formed at the rift centre with lateral migration of melt 592 occurring along conjugate fractures (Jolly \& Sanderson 1995) to generate the existing 593 regional dyke swarm. In addition, it is possible that the SMLS and MPLF lavas were 594 generated at $\mathrm{T}_{\mathrm{P}} \mathrm{c} .1450^{\circ} \mathrm{C}$, approximately $70^{\circ} \mathrm{C}$ lower than $\mathrm{T}_{\mathrm{P}}$ for the tholeiitic rocks of the 595 IJDS.

596 Whether magmatism in the Hebridean Basins would have occurred if the extensional 597 tectonism driven by plate-boundary forces had not taken place requires further investigation. 598 But, with a plume head at $\mathrm{T}_{\mathrm{P}} \geq 1550^{\circ} \mathrm{C}$ beneath Greenland, the Atlantic could have opened 599 along the line of what is now the Labrador Sea. It seems reasonable to suggest that rifting 600 failed in West Greenland because plate-boundary forces transferred stresses to the East, and 601 allowed magmatism to occur in the developing Rockall Trough and the basins to its northeast, 602 albeit at lower $\mathrm{T}_{\mathrm{P}}\left(\leq 1520^{\circ} \mathrm{C}\right)$. Subsequent migration of the plume-head to the East, beneath an 603 already weakened lithosphere accompanied opening of the Atlantic Ocean at its present 604 position.

\section{Conclusions}

606 Intrusions from the regional dyke swarm of the southwest of the BPIP exhibit variations in 607 isotopic compositions that can be readily explained by $\leq 6 \%$ assimilation with fractional 608 crystallization of Archean Lewisian granulite, or Proterozoic Moine and Dalradian 609 metasedimentary rocks. A significant number of intrusions have $\varepsilon \mathrm{Nd}_{58}$ in the range 3.0 to 9.3 610 and plot close to the NHRL-geochron intersection in terms of Pb-isotope compositions. These represent some of the least contaminated magmas in the BPIP, and consequently preserve the

612 isotopic and trace element characteristics of the mantle source-region from which they were 613 derived, which was very close to that of the source of modern ORB from the Mid Atlantic 614 Ridge. 
Large melt-fractions, generated in the spinel stability field of the upper-mantle, occur in

areas of limited crustal stretching suggesting that migration of melt from areas of more significant crustal attenuation occurred. The lava fields of Skye and Mull require limited extents of melting with garnet \pm spinel on the dry peridotite solidus. This is likely to be a consequence of thicker lithosphere beneath these locations than elsewhere in the region.

Forward modelling of major element compositions show that the highest temperature, largest melt fractions, in the BPIP were generated from upper-mantle with a $\mathrm{T}_{\mathrm{P}} \geq 1520^{\circ} \mathrm{C}$. Data for melt inclusions in olivine from mildly alkaline MPLF lavas suggest $T_{P}$ of 1300$1460^{\circ} \mathrm{C}$ which is within the range for ambient upper mantle. By comparison, synchronous picrite lavas at Baffin Island and Disko Island require higher $T_{P}$, of $\geq 1550^{\circ} \mathrm{C}$ and consequently represent the surface expression of the proto-Iceland plume head.

The main control on melting and the regional distribution of magmatism in the BPIP appears to be tectonic. Plate boundary forces resulted in rifting along the Rockall Trough and in the basins to its northeast, allowing melting on the periphery of the plume centred beneath West Greenland. The emplacement of large melt fractions into developing grabens, allowed magma storage and AFC to occur at shallow crustal levels, and in some cases, at close to 1 atm. Localized spatial and or temporal variations in $T_{P}$ within the BPIP during the period 63$58 \mathrm{Ma}$ cannot be ruled out as a mechanism for contributing to its magmatic diversity.

\section{Acknowledgements}

Research in the BTIP was supported by NERC grant GR9/1581, and the Carnegie Trust for the Universities of Scotland. Hugh Rollinson and Esteban Gazel are thanked for helpful and constructive criticisms, particularly of the modelling aspects of the paper, and Tyrone Rooney is thanked for invaluable scientific and editorial assistance. 


\section{References Cited}

640

641

642

643

644

645

646

647

648

649

650

651

652

653

654

655

656

657

658

659

660

661

662

663

664

665

666

667

668

669

670

671

672

Archer, S.A., Bergman, S.C., Illiffe, J., Murphy, C.M. \& Thorton, M. 2005. Palaeogene igneous rocks reveal new insights into the geodynamic evolution and petroleum potential of the Rockall Trough, NE Atlantic Margin. Basin Research, 17, 171-201.

Artemieva, I.M. \& Thybo, H. 2013. EUNAseis: A seismic model for Moho and crustal structure in Europe, Greenland, and the North Atlantic region. Tectonophysics, 609, 97153.

Bailey, E.B., Clough, T.C., Wright, W.B., Richey, J.E. \& Wilson, G.V. 1924. The Tertiary and post-Tertiary geology of Mull, Lochaline and Oban. Memoirs of the Geological Survey of the United Kingdom. His Majesty's Stationery Office, Glasgow. 422pp.

Barrat, J.A. \& Nesbitt, R.W. 1996. Geochemistry of Tertiary volcnaism of Northern Ireland. Chemical Geology, 129, 15-38.

Beattie, P., Ford, C. \& Russel, D. 1993. Partition coefficients for olivine-melt and orthopyroxene-melt systems. Contributions to Mineralogy \& Petrology, 115, 103-111.

Bell, B.R. \& Williamson, I.T. 1994. Picritic basalts from the Palaeocene lava field of westcentral Skye, Scotland: evidence for parental magma compositions. Mineralogical Magazine, 58, 347-356.

Bell B. R., Claydon R. V. \& Rogers G. 1994. The petrology and geochemistry of cone-sheets from the Cullin igneous complex, Isle of Skye: evidence for combined assimilation and fractional crystallization during lithospheric extension. Journal of Petrology, 35, 10551094

Chambers, L.M. \& Fitton, J.G. 2000. Geochemical transitions in the ancestral Iceland plume: evidence from the Isle of Mull Tertiary volcano, Scotland. Journal of the Geological Society, London, 157, 261-263.

Coltice, N., Bertrand, H., Rey, P.M., Jourdan, F., Phillips, B.R. \& Ricard, Y. 2009. Global warming of the mantle beneath continents back to the Archaean. Gondwana Research, 15, 254-266.

Coogan, L.A., Saunders, A.D. \& Wilson, R.N. 2014. Aluminium-in-olivine thermometry of primitive basalts: Evidence of an anomalously hot mantle source for large igneous provinces. Chemical Geology, 368, 1-10.

Corfield, S., Murphy, N. \& Parker, S. 1999. The structural and stratigraphic framework of the Irish Rockall Trough. In: Fleet, A. J. \& Boldy, S. A. R. (eds) Petroleum Geology of Northwest Europe: Proceedings of the 5th Conference, 407-420. Geological Society, London. 
Dale, C.W., Pearson, D.G., Starkey, N.A., Stuart, F.M., Ellan, R.M., Larsen, L.M. Fitton, J.G. \& Macpherson, C.G. 2008. Osmium isotopes in Baffin Island and West Greenland picrites: Implications for the ${ }^{187} \mathrm{Os} /{ }^{188} \mathrm{Os}$ composition of the convecting mantle and the nature of high ${ }^{3} \mathrm{He} /{ }^{4} \mathrm{He}$ mantle. Earth and Planetary Science Letters, 278, 267-277.

Dickin, A.P. \& Durant, G.P. 2002. The Blackstones Bank igneous complex: geochemistry and crustal context of a submerged Tertiary igneous centre in the Scottish Hebrides. Geological Magazine, 139, 199-207.

Dickin, A.P., Jones, N.W., Thirlwall, M.F. \& Thompson, R.N. 1987. A Ce/Nd isotope study of crustal contamination processes affecting Paleocene magmas in Skye, Northwest Scotland. Contributions to Mineralogy \& Petrology, 96, 455-464.

Doré, A.G., Lundin, E.R., Fichler, C. \& Olesen, O. 1997. Patterns of basement structure and reactivation along the NE Atlantic margin. Journal of the Geological Society, London, 154, 85-92.

Downes, H., Upton, B.G.J., Connolly, J., Beard, A.D. \& Bodinier, J-L 2007. Evidence for late Palaeozoic crustal underplating beneath SW Scotland Petrology and geochemistry of a cumulate xenolith suite from Bute. Journal of the Geological Society, London, 164, $1217-$ 1231.

Ellam, R.M. \& Stuart, F. 2000. The Sub-lithospheric source of North Atlantic basalts: Evidence for, and significance of, a common end-member. Journal of Petrology, 41, 919932.

England, R.W. 1988. The early Tertiary stress regime in NW Britain: evidence from the patterns of volcanic activity. In: Morton, A. C. \& Parson, L. M. (eds) Early Tertiary volcanism and the opening of the NE Atlantic. Geological Society, London, Special Publications, 39, 381-390.

Esson J., Dunham A.C. \& Thompson R.N. 1975. Low alkali, high Ca, olivine tholeiite lavas from the Isle of Skye, Scotland. Journal of Petrology, 16, 488-497

Faithfull, J.W., Timmerman, M.J., Upton, B.G.J. \& Rumsey, M.S. 2012. Mid-Eocene renewal of magmatism in NW Scotland: the Loch Roag Dyke, Outer Hebrides. Journal of the Geological Society, London, 169, 115-118.

Falloon, T.J., Danyushenvsky, L.V., Ariskin, A., Green, D.H. \& Ford, C.E. 2007. The application of olivine geothermometry to infer crystallization temperatures of parental liquids: Implications for the temperature of MORB magmas. Chemical Geology, 241, $207-$ 233 , 
Fitton, J.G., Saunders, A.D., Norry, M.J., Hardarson, B.S. \& Taylor R.N. 1997. Thermal and chemical structure of the Iceland plume. Earth and Planetary Science Letters, 153, 197208.

Fitton, J.G., Saunders, A.D., Larsen, L.M., Hardarson, B.S., \& Norry, M.J. 1998. Volcanic rocks from the southeast Greenland margin at $63^{\circ} \mathrm{N}$ : composition petrogenesis and mantle sources. In: Saunders, A.D., Larsen, H.C., Clift, P.D. et al., Proceedings of the Ocean Drilling Programme, Scientific Results 152, College Station, Texas. 331-350.

Font, L., Davidson, J.P., Pearson, D.G., Nowell, G.M., Jerram, D.A. \& Ottley, C.J. 2008. Sr and $\mathrm{Pb}$ Isotope Micro-analysis of Plagioclase Crystals from Skye Lavas: an Insight into Open-system Processes in a Flood Basalt Province. Journal of Petrology, 49, 1449-1471.

Foulger, G.R. 2012. Are 'hot spots' hot spots ? Journal of Geodynamics, 58, 1-28.

Fougler, G.R. \& Anderson, D.L. 2005. A cool model for the Iceland hotspot. Journal of Volcanology \& Geothermal Research, 141, 1-22.

Fowler, S.J., Bohrson, W.A. \& Spera, F.J. 2003. Magmatic Evolution of the Skye Igneous Centre, Western Scotland: Modelling of Assimilation, Recharge and Fractional Crystallization. Journal of Petrology, 45, 2481-2505.

Funck, T., Andersen, M. S., Neish, J. K. \& Trine, D-J. 2008. A refraction seismic transect from the Faroe Islands to the Hatton-Rockall Basin. Journal of Geophysical Research, 113, B12405.

Halliday, A.N., Dickin, I.P., Hunter, R., Davies, G.R., Dempster, T.J., Hamilton, P.J. \& Upton, B.G.J. 1993. Formation and Composition of the Lower Continental Crust: Evidence From Scottish Xenolith Suites. Journal of Geophysical Research, 91, 581-607.

Hamilton, M.A., Pearson, D.G., Thompson, R.N., Kelley, S.P. \& Emeleus, C.H. 1998. Rapid eruption of Skye lavas inferred from precise $\mathrm{U}-\mathrm{Pb}$ and $\mathrm{Ar}-\mathrm{Ar}$ dating of the Rum and Cuillin plutonic complexes. Nature, 384, 260-263.

Hansen, J, Jerram, D.A., McCaffrey, K. \& Passey, S.R. 2009. The onset of the North Atlantic Igneous Province in a rifting perspective. Geological Magazine, 146, 309-325.

Harker, A. 1904. The Tertiary Igneous rocks of Skye. Memoirs of the Geological Survey of the United Kingdom. His Majesty's Stationery Office, Glasgow. 481pp.

Hart, S.R. 1984. A large-scale isotope anomaly in the Southern Hemisphere mantle. Nature, 309, 753-75.

Herzberg, C. 2011. Basalts as temperature probes of Earth's mantle. Geology, 39, 1179-1180. 
Herzberg, C. \& Asimow, P.D. 2008. Petrology of some oceanic island basalts: PRIMELT2.XLS software for primary magma calculation. Geochemistry, Geophysics, Geosystems, 9.

Herzberg, C. \& Gazel, E. 2009. Petrological evidence for secular cooling in mantle plumes. Nature, 458, 619-623.

Herzberg, C., Asimow, P.D., Arndt, N., Niu, Y., Lesher, C.M., Fitton, J.G., Cheadle, M.J. \& Saunders, A.D. 2007. Temperatures in ambient mantle and plumes: Constraints from basalts, picrites, and komatiites. Geochemistry, Geophysics, Geosystems, 8, 1-34.

Hirschmann, M.M. 2000. Mantle solidus: Experimental constraints and the effects of peridotite composition. Geochemistry, Geophysics, Geosystems, 1, 1-34.

Hitchen, K, Morton, A.C., Mearns, E.W. Whitehouse, M. \& Stoker, M.S. 1997. Geological implications from geochemical and isotopic studies of Upper Cretaceous and Lower Tertiary igneous rocks around the northern Rockall Trough. Journal of the Geological Society, London, 154, 517-521.

Hole, M.J. \& Morrison, M.A. 1992. The differentiated dolerite boss, Cnoc Rhaonastil, Islay: a natural experiment in the low pressure differentiation of an alkali olivine-basalt magma. Scottish Journal of Geology, 28, 55-69.

Howell, S.M., Garrett, I., Breivik, A.J., Rai, A., Mjelde, R., Hanan, B., Sayit, K. \& Vogt, P. 2014. The origin of the asymmetry in the Iceland hotspot along the Mid-Atlantic Ridge from continental break-up to present day. Earth and Planetary Science Letters, 392, 143153.

Hunt, A.C., Parkinson, I.J., Harris, N.B.W., Barry, T.L., Rogers, N.W. \& Yondon, M. 2012. Cenozoic volcanism on the Hangai Dome,central Mongolia: geochemical evidence for changing melt sources and implications for mechanisms of melting. Journal of Petrology, 53, 1913-1942.

Jolley, D.W. \& Bell, B.R. 2002a. The evolution of the North Atlantic Igneous Province and the opening of the NE Rift. In: Jolley, D.W. \& Bell, B.R. (eds). The North Atlantic Igneous Province: Stratigraphy, Tectonic, Volcanic and Magmatic Processes. Geological Society, London, Special Publications, 197, 1-13.

Jolley, D.W. \& Bell, B.R. 2002b. Genesis of the Erland Volcano, NE Altantic margun. . In: Jolley, D.W. \& Bell, B.R. (eds). The North Atlantic Igneous Province: Stratigraphy, Tectonic, Volcanic and Magmatic Processes. Geological Society, London, Special Publications, 197, 95-110. 
Jolly, R.J.H. \& Sanderson, D.J. 1995. Variation in the form and distribution of dykes in the Mull swarm, Scotland. Journal of Structural Geology, 17, 1543-1557.

Keiding, J.K., Trumbull, R.B., Veksler, I.V. \& Jerram, D.A. 2011. On the significance of ultra-magnesian olivines in basaltic rocks. Geology, 39, 1095-1098.

Kent, R.W. \& Fitton, J.G. 2000. Mantle sources and melting dynamics in the British Palaeogene Igneous Province. Journal of Petrology, 41, 1023-1040.

Kerr, A.C. 1995. The geochemistry of the Tertiary Mull-Morvern lava succession, NW Scotland: an assessment of mantle sources during plume-related volcanism. Chemical Geology, 122, 43-58.

Kerr, A.C. 1998. Mineral chemistry of the Mull-Morvern Tertiary lava succession, western Scotland. Mineralogical Magazine, 62, 295-312.

Kerr, A.C., Kempton, P.D. \& Thompson, R.N. 1995. Crustal assimilation during turbulent magma ascent (ATA); new isotopic evidence from the Mull Tertiary lava succession, N. W. Scotland. Contributions to Mineralogy and Petrology, 119, 142-154.

Kerr, A.C., Kent, R.W., Thomson, B.A., Seedhouse, J.K. \& Donaldson, C.H. 1999. Geochemical Evolution of the Tertiary Mull Volcano, Western Scotland. Journal of Petrology, 40, 873-908.

Kimbell, G.S., Ritchie, J.D. \& Henderson, A.F. 2010. Three-dimensional gravity and magnetic modelling of the Irish sector of the NE Atlantic margin. Tectonophysics, 486, 3654.

Klingelhöfer, F., Edwards, R.A., Hobbs, R.W. \& England, R.W. 2005. Crustal structure of the NE Rockall Trough from wide-angle seismic data modelling. Journal of Geophysical Research, 110, B11105.

Lawver, L.A. \& Müller, R.D. 1994. The Iceland hotspot track. Geology, 22, 311-314.

Larsen L. M. \& Pedersen A. K. 2000. Processes in high-Mg, high-T magmas: evidence from olivine, chromite and glass in Paleogene picrites from West Greenland. Journal of Petrology, 41, 1071-1098

Lightfoot, P.C., Hawkesworth, C.J., Olshefsky, K., Green, T. Doherty, W \& Keays, R.R. 1997. Geochemistry of Tertiary tholeiites and picrites from Qeqertarssuaq (Disko Island) and Nuussuaq, West Greenland with implications for the mineral potential of comagmatic intrusions. Contributions to Mineralogy and Petrology, 128, 139-163.

Lyle, P. \& Preston, J. 1993. Geochemistry and volcanology of the Tertiary basalts of the Giant's Causeway area, Northern Ireland. Journal of the Geological Society, London, 150, 109-120. 
Lyle, P. 2000. The eruption environment of multi-tiered colum,nar basalt lava flows. Journal of the Geological Society, London, 157, 715-722.

Lyle, P. 2001. Phase Relationships within the Causeway Tholeiite Member of the Tertiary Antrim Lava. Irish Journal of Earth Sciences, 19, 37-41.

Macdonald, R., Baginski, B., Upton, B.G.J., Pinkerton, H., Macinnes, D.A. \& MacGillivray, J.C. 2010. The Mull Palaeogene dyke swarm: insights into the evolution of the Mull igneous centre and dyke-emplacement mechanisms. Mineralogical Magazine, 74, 601-622.

Maculloch, J. 1819. A description of the Western Isles of Scotland, including the Isle of Man: comprising an account of their Geological Structure: with remarks on their Agriculture, Scenery and Antiquities. Hurst, Robinson \& Co. London. Volume II, 618pp.

Marcantonio, F., Dickin, A.P., McNutt, R.H. \& Heaman, L.M. 1988. A 1,800-million-yearold Proterozoic gneiss terrane in Islay with implications for the crustal structure and evolution of Britain. Nature, 335, 62-64.

McAteer, C.A., Daly, S., Flowerdew, M.J. \& Whitehouse, M. 2010. Dalradian Grampian Group affinity for the Bowmore Sandstone Group, Islay, SW Scotland. Scottish Journal of Geology, 46, 97-111.

McKenzie, D.P. \& Bickle, M.J. 1988. The volume and composition of melt generated by extension of the lithosphere. Journal of Petrology, 29, 625-679.

McKenzie, D.P. \& O’Nions, R.K. 1995. The source region of Ocean Island basalts. Journal of Petrology, 36, 133-159.

Menzies, M. \& Halliday, A. 1988. Lithospheric Mantle Domains beneath the Archean and Proterozoic crust of Scotland. Journal of Petrology, Special Lithosphere Issue, 275-302.

Mihalffy, P., Steinberger, B. \& Schmeling, H. 2008. The effect of the large-scale mantle flow field on the Iceland hotspot track. Tectonophysics, 447, 5-18

Moorbath, S. \& Thompson, R.N. 1980. Strontium isotope geochemistry and petrogenesis of the early Tertiary lava pile of Skye, Scotland, and other basic rocks of the British Tertiary province: an example of magma-crust interaction. Journal of Petrology, 21, 295-321.

Morrison, M.A., Thompson, R.N. \& Dickin, A.P. 1985. Geochemical evidence for complex magmatic plumbing during development of a continental volcanic centre. Geology, 13, 581-584.

Morton, A.C. \& Taylor P.N. 1991. Geochemical and isotopic constraints on the nature and age of basement rocks from Rockall Bank, NE Atlantic. Journal of the Geological Society, London, 148, 631-634. 
Morton, A.C., Dixon, J.E., Fitton, J.G., Macintyre, R.M., Smythe, D.K. \& Taylor, P.N. 1988. Early Tertiary volcanic rocks in well 163/6-1A, Rockall Trough. In: Morton, A.C. \& Parsons, L.M. (eds): Early Tertiary Volcanism and the opening of the NE Atlantic. Geological Society, London, Special Publications, 39, 293-308.

Morton, A.C., Hitchin, K., Ritchie, J.D., Hine, N.M., Whitehouse, M. \& Carter, S.G. 1995. Late Cretaceous basalts from Rosemary Bank, Northern Rockall Trough. Journal of the Geological Society, London, 152, 947-952.

Muir, R.J., Fitches, W.R. \& Maltman, A.J. 1994. The Rhinns Complex: Proterozoic basement on Islay, Colonsay, Inner Hebrides, Scotland, and on Inishtrahull, NW Ireland. Transactions of the Royal Society of Edinburg, Earth Sciences, 85, 77-90.

Murton, B.J., Taylor, R.N. \& Thirlwall, M.F. 2002. Plume-ridge interaction: a geochemical perspective from the Reykjanes Ridge. Journal of Petrology, 43, 1155-1176.

Nielsen, S.B., Stephenson, R.A. \& Thomsen, E. 2007. Dynamics of Mid-Palaeocene North Atlantic rifting linked with European intra-plate deformations. Nature, 450, 1071-1074

O’Connor, J.M., Stoffers, P., Wijbrans, J.R., Shannon, P.M. \& Morrissey, T. 2000. Evidence from episodic seamount volcanism for pulsing of the Iceland plume in the past $70 \mathrm{Myr}$. Nature, 408, 954-956.

Pearson, D.G., Emeleus, C.H. \& Kelley, S.P. 1996. Precise ${ }^{40} \mathrm{Ar} /{ }^{39} \mathrm{Ar}$ age for the initiation of Palaeogene volcanism in the Inner Hebrides and its regional significance. Journal of the Geological Society, London, 158, 815-818.

Peate, D.W., Peat, I.U., Rowe, M.C., Thompson, J.M. \& Kerr, A.C. 2012. Petrogenesis of High-MgO lavas of the Lower Mull Plateau Lava Formation, Scotland: insights from melt inclusions. Journal of Petrology, 53, 1867-1886

Perfit, M.R., Form, D.J., Ridley, W.I., Kirk, P.D., Casey, D.J., Kastens, K.A., Reynolds, J.R., Edwards, M., Desonie, D., Shuster, R. \& Paradis, S. 1996. Recent volcanism in the Siqueiros transform fault: picritic basalts and implications for MORB magma genesis. Earth and Planetary Science Letters, 141, 91-108.

Pertermann, M. Hirschmann, M.M., Hametner, K, Gunther, D. \& Schmidt, M.W. 2004. Experimental determination of trace element partitioning between garnet and silica-rich liquid during anhydrous partial melting of MORB-like eclogite. Geochemistry, Geophysics, Geosystems, 5, 1-23.

Preston, R.J., Bell, B.R. \& Rogers, G. 1998. The Loch Scridain Xenolithic Sill Complex, Isle of Mull, Scotland: Fractional Crystallization, Assimilation, Magma-Mixing and Crustal Anatexis in Subvolcanic Conduits. Journal of Petrology, 39, 519-550. 
872

873

874

875

876

877

878

879

880

881

882

883

884

885

886

887

888

889

890

891

892

893

894

895

896

897

898

899

900

901

902

903

904

905

Putirka, K.D. 2008. Thermometers and Barometers for Volcanic Systems. Reviews in Mineralogy \& Petrology, 69, 61-120.

Putirka, K.D., Perfit, M., Ryerson, F.J. \& Jackson, M.G. 2007. Ambient and excess mantle temperatures, olivine thermometry, and active vs. passive upwelling. Chemical Geology, 241, 177-206.

Ritchie, J.D. \& Hitchen, K. 1996. Early Paleogene offshore igneous activity to the northwest of the UK and its relationship to the North Atlantic Igneous Province. In: Knox, R.W.O’B., Corfield, R.M. \& Dunay, R.E. (eds). Correlation of the Early Palaeocene in Northwestern Europe. Geological Society, London, Special Publications, 101, 63-78.

Rollinson, H. 2012. Geochemical constraints on the composition of Archaean lower continental crust: Partial melting in the Lewisian granulites. Earth and Planetary Science Letters, 351-352, 1-12.

Saunders, A.D., Fitton J.G., Kerr, A.C., Norry, M.J. \& Kent, R.W. 1997. The North Atlantic Igneous Province. In: Mahoney, J.J. \& Coffin, M.F. (eds) Large Igneous Provinces: Continental, Oceanic and Planetary Volcanism. Geophysical Monograph, American Geophysical Union, 100, 45-93.

Saunders, A.D., Larsen, H.C. \& Fitton, J.G. 1998. Magmatic development of the southeast Greenland margin and evolution of the Iceland plume: geochemical constraints from leg 152. In: Saunders, A. D., Larsen, H. C., Clift, P. D. et al., (eds) Proceedings of the Ocean Drilling Programme, Scientific Results 152, College Station, Texas. 479-501.

Scarrow, J.H. \& Cox, K.G. 1995. Basalts generated by decompressive adiabatic melting of a mantle plume: a case study from the Isle of Skye, NW Scotland. Journal of Petrology, 36, 3-22.

Scarrow, J.H., Curran, J.M. \& Kerr, A.C. 2000. Major element records of variable plume involvement in the North Atlantic Province Tertiary Flood Basalts. Journal of Petrology 41, 1155-1176.

Shorttle, O., Maclennan, J. \& Lambart, S. 2014. Quantifying lithological variability in the mantle. Earth \& Planetary Science Letters, 395, 24-40.

Smedley, P.L. 1986. The relationship between calc-alkaline volcanism and within-plate continental rift volcanism: evidence from Scottish Palaeozoic lavas. Earth and Planetary Science Letters, 76, 113-128.

Sobolev, A.V., Hofmann, A.W., Kuzmin, D.V., Yaxley, G.M., Arndt, N.T., Chung, S.-L., Danyushevsky, L.V., Elliott, T., Frey, F.A., Garcia, M.O., Gurenko, A.A., Kamenetsky, V.S., Kerr, A.C., Krivolutskaya, N.A., Matvienkov, V.V., Nikogosian, I.K., Rocholl, A., 
Sigurdsson, I.A., Sushchevskaya, N.M. \& Teklay, M. 2007. The amount of recycled crust in sources of mantle-derived melts. Science, 316, 412-417.

Speight, J.M., Skelhorn, R.R., Sloan,T. \& Knapp, R.J. 1982. The dyke swarms of Scotland. In: Sutherland, D.S. (ed.) The Igneous Rocks of the British Isles. Chichester: Wiley, 449-459.

Starkey, A.A., Stuart, F.M., Ellam, R.M., Fitton J.G., S, Basu \& Larsen L. M. 2009. Helium isotopes in early Iceland plume picrites: constraints on the composition of high ${ }^{3} \mathrm{He} /{ }^{4} \mathrm{He}$ mantle. Earth and Planetary Science Letters, 277, 91-100.

Sun, S-S. \& McDonough, W.F. 1988. Chemical and isotopic systematics of oceanic basalts: implications for mantle composition and processes. In: Saunders, A. D. \& Norry, M. J. (eds) Magmatism in the ocean basins. Geological Society, London, Special Publications, 42, 313-345.

Tate, M.P., Dodd, C.D. \& Grant, N.T. 1999. The Northeast Rockall Basin and its significance in the evolution of the Rockall-Faeroes/East Greenland rift system. In: Fleet, A.J. \& Boldy, S.A.R. (eds). Petroleum Geology of Northwestern Europe: Proceedings of the $5^{\text {th }}$ Conference. Geological Society, London, 391-406.

Thompson, R.N. 1974. Primary basalts and magma genesis I: Skye, North-West Scotland. Contributions to Mineralogy and Petrology, 45, 317-341.

Thompson, R.N. 1982. Magmatism in the British Tertiary Volcanic Province. Scottish Journal of Geology, 18, 49-107

Thompson, R.N. \& Morrison, M.A. 1988. Asthenospheric and lower lithospheric mantle contributions to continental extensional magmatism: an example from the British Tertiary Province. Chemical Geology, 68, 1-15.

Thompson, R.N., Esson, J. \& Dunham, A.C. 1972. Major element chemical variations in the Eocene lavas of the Isle of Syke, Scotland. Journal of Petrology, 13, 219-253

Thompson, R.N., Gibson, I.L., Marriner, G.F., Mattey, D.P. \& Morrison, M.A. 1980. Trace element evidence of multistage mantle fusion and polybaric fractional crystallisation in the Palaeocene lavas of Skye, NW Scotland. Journal of Petrology, 21, 265-293.

Thompson, R.N., Dickin, A.P., Gibson, I.L. \& Morrison, M.A. 1982. Elemental fingerprints of isotopic contamination of Hebridean Palaeocene mantle-derived magmas by Archaean Sial. Contributions to Mineralogy and Petrology, 79, 159-168.

Thompson, R.N., Morrison, M.A., Dickin, A.P., Gibson, I.L. \& Harmon, R.S. 1986. Two contrasting styles of interaction between basic magmas and continental crust in the British Tertiary Volcanic Province. Journal of Geophysical Research, 91, 5985-5997. 
939 Ulmer, P. 1989. The dependence of the $\mathrm{Fe}^{2+}-\mathrm{Mg}$ cation-partitioning between olivine and 940 basaltic liquid on pressure, temperature and composition. Contributions to Mineralogy and 941 Petrology, 101, 261-273.

942 Wallace, J.M., Ellam, R.M., Meighan, I.G., Lyle, P. \& Rogers, N.W. 1994. Sr isotope data for 943 the Tertiary lavas of Northern Ireland: evidence for open-system petrogenesis. Journal of 944 the Geological Society, London, 151, 869-878.

945 Weng, Y-H \& Presnall, D.C. 2001. the system diopside - forsterite - enstatite at 5.1 GPa: a 946 ternary model for melting of the mantle. The Canadian Mineralogist, 39, 299-308.

947 Williamson, I.T. \& Bell, B.R. 2012. The Staffa Lava Formation: graben-related volcanism, 948 associated sedimentation and landscape character during the early development of the 949 Palaeogene Mull Lava Field, NW Scotland. Scottish Journal of Geology, 48, 1-46.

950 Ziska, H. \& Varming, T. 2008. Palaeogene evolution of the Ymir and Wyville Thomson 951 ridges,European North Atlantic margin. In: Johnson, H., Dore, A.G., Gatliff, R.W., 952 Holdsworth, R., Lundin, E.R. \& Ritchie, J.D. (eds) The Nature and Origin of Compression 953 in Passive Margins. Geological society, London, Special Publications, 306, 153-168. 
Figure 1 a) Map of the continental shelf West of the British Isles. Position of offshore igneous centres

957

958

959

960

961

962

963

964

965

966

967

968

969

970

971

972

973

974

975

976

977

978

979

980

981

982

983

984

985

986

987

988

989 and dyke swarms from Speight et al. (1982), England (1988), Ritchie \& Hitchen (1996), Dore et al. (1997), Jolly \& Sanderson (1998), Archer et al. (2005) and Kent \& Fitton (2000). Seismic refraction profiles from Corfield et al. (1999), Klingerhöfel et al. (2005) and Funck et al. (2008), the profile lines being indicated on the map. Abbreviations for igneous centres; LB, Lousy Bank; BBB, Bill Bailey Bank; FBC, Faroe Bank Centre; FCK, Faroe Centre Knoll; D, Darwin; S, Sigmundur; RB, Rosemary Bank. b) Distribution and azimuth of regional dyke swarms of the BPIP. Stippled areas are sedimentary basins, and the Islay-Instrahul-Rockall Terrane is shown. The rose diagram shows the azimuths of the intrusions sampled in this study, and those from Jolly \& Sanderson (1998) for the Mull dyke swarm.

Figure 2. a) Normative $\mathrm{Di}, \mathrm{Hy}, \mathrm{Ol}$ and $\mathrm{Ne}$ in IJDS basalts with $8-12$ weight $\% \mathrm{MgO}$. The cotectic curves at 1 atmosphere and $0.9 \pm 0.15 \mathrm{GPa}$ (anhydrous) are for the equilibria olivine + plagioclase + clinopyroxene + natural basic liquid. Solid line arrows mark the directions of falling temperature on these cotectics. Filled circles, IJDS basalts; open circles, Causeway tholeiites (Lyle \& Preston 1993); filled squares, Loch Scridain Sill Complex (Preston et al. 1998); open squares, Skye cone sheets (Bell et al. 1994); filled triangles, Skye picrites (Bell \& Williamson 1994); open diamonds, Staffa Lava Formation, Ardtun, Mull (this study); filled diamonds, staffa Lava Formation, Ulva Ferry (this study). Crosses are the data points used to construct the $0.9 \pm 0.15$ GPa cotectic. After Thompson (1982) and Hole \& Morrison (1992) and b) normative compositions of Central Mull Tholeiite formation dykes from the Outer Isles Dyke Swarm (Kent \& Fitton, 2000). The pecked arrow illustrates the effect of addition of equilibrium olivine in $0.5 \%$ increments, up to a maximum of $20 \%$, to basalt MHI2.10.

Figure 3. Major and trace element variations for the Islay-Jura dyke swarm (left-hand diagrams) and BPIP lavas (right-hand diagrams). For the IJDS, filled symbols are for Hy-normative Si-saturated compositions, and open symbols are for Ne-normative Si-undersaturated compositions (see Fig. 2). Filled diamonds, Mull Plateau Lava Formation (MPLF) of Ben More (Kerr et al. 1999); open circles, Coire Gorm Formation (CGF) of Ben More (Kerr et al. 1999); open triangles, Causeway Tholeiite Member (CTM), Antrim (Wallace et al. 1994; Barrat \& Nesbit 1996); filled triangles, Staffa Lava Formation (SLF) this study, and Morrison et al. (1985). In the left-hand panel, the pecked line is the trend for the MPLF and the solid line that for the CTM and SLF. The inflexion on the pecked line in the $\mathrm{CaO}$ versus $\mathrm{Mg} \#$ diagram represents the beginning of augite fractionation with decreasing $\mathrm{Mg} \#$ for the MPLF. The pecked arrow on the IJDS diagrams is as for Fig. 2.

Figure 4. a) to c) REE profiles for Islay dykes. Normalizing values from Sun \& McDonough (1988). Figures in square brackets are $\varepsilon \mathrm{Nd}_{58}$ and ${ }^{206} \mathrm{~Pb} /{ }^{204} \mathrm{~Pb}$ ratios, respectively, for the preceding sample number. 
990

991

992

993

994

995

996

997

998

999

1000

1001

1002

1003

1004

1005

1006

1007

1008

1009

1010

1011

1012

1013

1014

1015

1016

1017

1018

1019

1020

1021

1022

1023

1024

1025

1026

Figure 5. a) ${ }^{207} \mathrm{~Pb} /{ }^{204} \mathrm{~Pb}$, b) $\varepsilon \mathrm{Nd}_{58}$ and c) $\delta^{18} \mathrm{O} \%$ versus ${ }^{206} \mathrm{~Pb} /{ }^{204} \mathrm{~Pb}$. Mixing lines are for $\mathrm{AFC}$ involving a mantle source with ${ }^{206} \mathrm{~Pb} /{ }^{204} \mathrm{~Pb}=17.5,0.2 \mathrm{ppm} \mathrm{Pb}, \varepsilon \mathrm{Nd}_{58}+10$ and $2 \mathrm{ppm} \mathrm{Nd}$ with; 1) Lewisian granulite facies acid gneiss (Rollinson 2012), with ${ }^{206} \mathrm{~Pb} /{ }^{204} \mathrm{~Pb}=14.5$ and $7 \mathrm{ppm} \mathrm{Pb} ; \varepsilon \mathrm{Nd}_{58}$ 50 with $50 \mathrm{ppm} \mathrm{Nd.} \mathrm{2)} \mathrm{average} \mathrm{Dalradian} \mathrm{pelite} \mathrm{(Morrison} \mathrm{et} \mathrm{al.} \mathrm{1985),} \mathrm{with}{ }^{206} \mathrm{~Pb} /{ }^{204} \mathrm{~Pb}=19.5$ and 7 ppm Pb; $\varepsilon \mathrm{Nd}_{58}-20$ with $30 \mathrm{ppm} \mathrm{Nd}$. Bulk partition coefficients are assumed to be 0.01 for both $\mathrm{Nd}$ and $\mathrm{Pb}$, and the ratio of assimilated rock to crystal cumulate formation is assumed to be 0.3 . Numbered data points are 1\% mixing. Northern Hemisphere Reference Line (NHRL) from Hart (1988). Filled triangles are Cnoc Rhaonastil dolerites from Hole \& Morrison (1992) and Dickin \& Durant (2002). In c) open triangles are lavas from the Staffa Lava Formation (Thompson et al 1986).

Figure $6 .{ }^{206} \mathrm{~Pb} /{ }^{204} \mathrm{~Pb}$ and $\varepsilon \mathrm{Nd}_{58}$ plotted versus $[\mathrm{La} / \mathrm{Sm}]_{\mathrm{N}}$ and $\mathrm{La} / \mathrm{Ta}$ ratios for IJDS basalts. Symbols as for Fig. 3.

Figure 7. a) La/Ta versus $\mathrm{Th} / \mathrm{Ta}$ for Islay dykes and other BPIP basalts with symbols as for Fig. 3 . AFC trajectories, with \% crystallization, have the following parameters; Lewisian granulite composition, $\mathrm{Th}=1.0 \mathrm{ppm} ; \mathrm{La}=65 \mathrm{ppm} ; \mathrm{Ta}=0.03 \mathrm{ppm}$ based on data in Rollinson (2012) and Thompson et al. (1984). Moine metasedimentary rock composition is based on average composition from Thompson et al. (1986); $\mathrm{Th}=13 \mathrm{ppm} ; \mathrm{La}=55 \mathrm{ppm} ; \mathrm{Ta}=0.8 \mathrm{ppm}$. The source composition is derived from GIG3.1 (Table 1), assuming this basalt underwent 30\% olivine fractionation prior to emplacement; $\mathrm{Th}=0.05 \mathrm{ppm} ; \mathrm{La}=0.8 \mathrm{ppm} ; \mathrm{Ta}=0.05 \mathrm{ppm}$. Bulk distribution coefficients were assumed to be 0.01 for all elements, and the ratio of assimilated rock to crystal cumulate was assumed to be $0.3 . \mathrm{b}$ ) the same mixing lines as a), but indexed for ${ }^{206} \mathrm{~Pb} /{ }^{204} \mathrm{~Pb}$ ratios and $\varepsilon \mathrm{Nd}_{58}$ (italics). Star in circle, most isotopically 'contaminated' Staffa lava from Morrison et al. (1985). Filled star, sample MHI5.3; open star, sample GIG5.5. Fields for the most isotopically 'contaminated' SMLS lavas, and CTM lavas are also shown, and the shaded area represents the composition of SMLS and Preshal More lavas which carry no evidence of isotopic contamination with crust. Data sources; Causeway Tholeiite Member, Wallace et al. (1994); SMLS lavas; Thompson et al. (1980, 1982, 1986); Moorbath \& Thompson (1980); Dickin et al. (1987); Font et al. (2008).

Figure 8. a) Olivine-whole-rock equilibration temperatures versus Mg\# for BPIP basalts, Baffin Island and Disko Island picrites and Siqueiros ORB. Calculated using the method of Putirka (2008). The pecked horizontal lines are the ranges of $T_{P}$ for MPLF melt inclusions shown in $b$ ), and the lines terminating in dots represent the maximum $T_{P}$ for melt inclusions in olivine from that sample. $b$ ) Mantle potential temperatures $\left(\mathrm{T}_{\mathrm{P}}\right)$ versus $\mathrm{Mg} \#$ calculated from $\mathrm{MgO}$ content of melt inclusions within olivine phenocrysts in MPLF lavas (Peate et al. 2012). $T_{P}$ was calculated assuming that the inclusions are near primary melts and therefore applying the formula $T_{P}=1463+12.75 \times \mathrm{MgO}-(2924 / \mathrm{MgO})$ from Herzberg et al. (2007). $\mathrm{T}_{\mathrm{P}}$ and primary magma Mg-number calculations on whole-rocks for the IJDS, MPLF, west and east Greenland picrites are results of the model of Herzberg \& Asmiow (2008) in this study, and from Herzberg \& Gazel (2009). Lines terminating with squares are ranges of $T_{P}$ calculated from olivine equilibration temperatures (Putirka et al. 2007) given in Table 2, and from Scarrow \& 
1027 Cox for the SMLS. Lines terminating in dots are $T_{P}$ ranges for average ambient mantle, the Iceland 1028 plume at $58 \mathrm{Ma}$ (Icld), and modern Hawaii taken from Herzberg \& Asimow (2008). Other data 1029 sources; Baffin Island, Starkey et al. (2009), Herzberg \& Gazel (2009); Siqueiros ORB, Perfit et al. 1030 (1996) and Coogan et al. (2014); MPLF lavas, Peate et al. (2012), Sobolev et al. (2007), Kerr (1998) 1031 and Kerr et al. (1999).

1032 Figure 9. a) Plot of $[\mathrm{Tb} / \mathrm{Yb}]_{\mathrm{N}}$ versus $[\mathrm{La} / \mathrm{Yb}]_{\mathrm{N}}$ for BPIP basalts. All samples plotted have $\varepsilon \mathrm{Nd}_{58}$ in the 1033 range 3.0-9.0. Filled dots, IJDS Hy-normative basalts; open dots, IJDS Ne-normative basalts; filled 1034 diamonds SMLS lavas (Thompson et al. 1980; 1982; 1986); open diamonds, MPLF lavas (Kerr et al. 1035 1995; 1999); open squares, Skye Cone Sheets (Bell et al. 1994); star-in-circles, Rosemary Bank 1036 (Morton et al. 1995); open triangles, 163/6-1A basalts (Morton et al. 1988); filled triangles, Antrim 1037 basalts (Barrat \& Nesbitt 1996; Wallace et al. 1994); stars, Preshal More tholeiites of Skye (Esson et 1038 al. 1975; Font et al. 2008). b) the same axes for Baffin Island picrites (Dale et al. 2008) and Disko 1039 Island picrites (Lightfoot et al. 1997; Larsen \& Pedersen 2000). On both diagrams, solid lines with 1040 crosses are melting trajectories with \% melting shown in b), for garnet and spinel lherzolite for a 1041 starting composition representing the source of 'non-plume' MAR basalts (Murton et al. 2002). 1042 Pecked lines are for melting of primitive mantle modified after Hunt et al. (2012).

1043 Figure 10. P-T diagram illustrating the region of melting for IJDS basalts. The dry solidus is taken 1044 from Hirschman (2000) and garnet-in and spinel-out contours from McKenzie \& Bickle (1988). 1045 Melting is assumed to take place at $10 \% \mathrm{GPa}^{-1}$. The line at $2.3 \mathrm{GPa}$ is the base of the mechanical 1046 boundary layer for normal thickness lithosphere of the BPIP as suggested by Kerr et al. (1999). 1047 Estimates of $\mathrm{T}_{\mathrm{P}}$ for 'ambient' north Atlantic mantle and the Iceland plume are indicated by names of 1048 authors along adiabats. The thick line with dots is the likely extent of a melt column beneath 1049 lithosphere of normal thickness beneath the BPIP for $T_{P}=1530^{\circ} \mathrm{C}$. The shaded triangle is the stability 1050 field for olivine + liquid for basalt 66018 (Thompson 1974). The two parallel horizontal lines at $10510.9 \pm 0.15 \mathrm{GPa}$, represent the range of base-of-the-crust fractionation pressures suggested by Thompson 1052 (1974) for SMLS lavas. Note that this pressure is within the olivine stability field for 66018.

1053 Figure 11. a) Depth to the Moho at latitude $62^{\circ} \mathrm{N}$ at present-day (Artemieva \& Thybo 2013) and b) 1054 before Chron 24 (c. 58Ma). The arrow on the lower figure gives the plume positions of Lawver \& 1055 Müller (1994) at the times labelled. 
Table 1.

\begin{tabular}{|c|c|c|c|c|c|c|c|c|}
\hline Sample \# & MHI12.2 & MHI9.3 & MHI9.7 & MHI7.2 & MHJ2.5 & MHI6.6 & GIG4.5 & MHI2.6 \\
\hline $\mathrm{SiO}_{2}$ & 46.13 & 45.85 & 46.90 & 47.47 & 44.46 & 46.34 & 45.59 & 46.68 \\
\hline $\mathrm{TiO}_{2}$ & 2.20 & 0.92 & 0.93 & 1.99 & 1.7 & 1.02 & 1.63 & 1.05 \\
\hline $\mathrm{Al}_{2} \mathrm{O}_{3}$ & 16.95 & 11.33 & 12.88 & 18.40 & 15.5 & 13.75 & 16.17 & 17.63 \\
\hline $\mathrm{Fe}_{2} \mathrm{O}_{3 \mathrm{~T}}$ & 14.79 & 11.13 & 10.86 & 13.88 & 14.55 & 14.39 & 14.39 & 12.28 \\
\hline $\mathrm{MnO}$ & 0.18 & 0.16 & 0.18 & 0.21 & 0.23 & 0.19 & 0.17 & 0.16 \\
\hline $\mathrm{MgO}$ & 6.24 & 17.80 & 15.20 & 4.84 & 11.18 & 10.43 & 8.98 & 9.06 \\
\hline $\mathrm{CaO}$ & 8.90 & 10.33 & 10.62 & 9.33 & 8.34 & 9.10 & 8.70 & 10.58 \\
\hline $\mathrm{Na}_{2} \mathrm{O}$ & 3.42 & 1.60 & 1.67 & 2.82 & 2.86 & 3.71 & 3.12 & 2.32 \\
\hline $\mathrm{K}_{2} \mathrm{O}$ & 0.22 & 0.05 & 0.05 & 0.18 & 0.76 & 0.02 & 0.19 & 0.14 \\
\hline $\mathrm{P}_{2} \mathrm{O}_{5}$ & 0.23 & 0.07 & 0.06 & 0.19 & 0.20 & 0.22 & 0.13 & 0.13 \\
\hline Total & 99.26 & 99.25 & 99.36 & 99.3 & 99.78 & 99.18 & 99.06 & 100.04 \\
\hline LOI & 4.48 & 1.86 & 2.30 & 4.03 & 4.86 & 1.51 & 4.92 & 2.70 \\
\hline \multicolumn{9}{|c|}{ Trace elements in ppm } \\
\hline $\mathrm{Cr}$ & 36 & 1319 & 900.3 & 36 & 229 & 342 & 124 & 35 \\
\hline $\mathrm{Ni}$ & 64 & 641 & 602 & 73 & 311 & 307 & 232 & 151 \\
\hline $\mathrm{Co}$ & 53.1 & 70.3 & 65.9 & 49.8 & 64.3 & 62.7 & 60 & 56.2 \\
\hline Cs & nd & & & 0.76 & 0.94 & 0.24 & 0.89 & \\
\hline $\mathrm{Rb}$ & 2 & 0.8 & 0.92 & 2 & 5.29 & 4.42 & 2 & 2 \\
\hline $\mathrm{Sr}$ & 392 & 138 & 133 & 510 & 488 & 226 & 329 & 176 \\
\hline $\mathrm{Ba}$ & 36 & 44 & 54.2 & 42 & 42.7 & 100 & 85 & 16 \\
\hline $\mathrm{Hf}$ & 4.05 & 1.3 & 1.22 & 3.38 & 3.03 & 2.8 & 2.88 & 1.68 \\
\hline $\mathrm{Zr}$ & 187.5 & 44 & 43.6 & 131 & 112 & 100.3 & 107 & 67.1 \\
\hline $\mathrm{Nb}$ & 2.4 & 0.4 & 0.4 & 2.8 & 2.3 & 2.2 & 2.1 & 0.9 \\
\hline $\mathrm{Ta}$ & 0.23 & 0.03 & 0.025 & 0.21 & 0.15 & 0.14 & 0.15 & 0.07 \\
\hline $\mathrm{Y}$ & 35.7 & 16 & 16.6 & 24.4 & 23 & 19.5 & 25 & 24.5 \\
\hline $\mathrm{Sc}$ & & 37 & 37.1 & 24.4 & 28.9 & 27.1 & & \\
\hline $\mathrm{Pb}$ & & 0.7 & 0.26 & & 1 & 1.72 & & \\
\hline $\mathrm{U}$ & & 0.01 & 0.01 & & 0.06 & 0.06 & & \\
\hline Th & 0.4 & 0.05 & 0.05 & 0.36 & 0.23 & 0.25 & 0.3 & 0.3 \\
\hline $\mathrm{La}$ & 5.3 & 1.5 & 1.4 & 6.6 & 3.61 & 5.42 & 3.7 & 2.5 \\
\hline $\mathrm{Ce}$ & 15 & 4.5 & 4.41 & 19.3 & 11.33 & 14.05 & 10.3 & 5.7 \\
\hline $\operatorname{Pr}$ & & 0.9 & 0.85 & & 2.16 & 2.35 & & \\
\hline $\mathrm{Nd}$ & 15.4 & 4.8 & 4.75 & 17.2 & 11.66 & 12.65 & 11.6 & 6.5 \\
\hline $\mathrm{Sm}$ & 5.32 & 1.9 & 1.88 & 4.65 & 4.04 & 3.68 & 3.85 & 2.34 \\
\hline $\mathrm{Eu}$ & 2.04 & 0.75 & 0.75 & 1.77 & 1.49 & 1.38 & 1.49 & 0.96 \\
\hline $\mathrm{Gd}$ & & 2.44 & 2.51 & & 4.63 & 4.06 & & \\
\hline $\mathrm{Tb}$ & 1.15 & 0.45 & 0.46 & 0.85 & 0.79 & 0.65 & 0.87 & 0.66 \\
\hline Dy & & 2.93 & 2.9 & & 4.77 & 3.75 & & \\
\hline Ho & & 0.59 & 0.59 & & 0.93 & 0.75 & & \\
\hline $\mathrm{Er}$ & & 1.63 & 1.61 & & 2.46 & 2.05 & & \\
\hline $\mathrm{Tm}$ & & 0.23 & 0.24 & & 0.36 & 0.29 & & \\
\hline $\mathrm{Yb}$ & 3.25 & 1.47 & 1.46 & 2.2 & 2.6 & 1.9 & 2.5 & 2.5 \\
\hline $\mathrm{Lu}$ & 0.52 & 0.23 & 0.21 & 0.34 & 0.31 & 0.29 & 0.39 & 0.39 \\
\hline${ }^{87} \mathrm{Sr} /{ }^{86} \mathrm{Sr}_{58}$ & 0.703943 & 0.703853 & 0.703761 & 0.704315 & 0.703939 & 0.703638 & 0.704308 & 0.704023 \\
\hline $2 \mathrm{se}$ & \pm 0.000015 & \pm 0.000017 & \pm 0.000017 & \pm 0.000017 & \pm 0.000017 & \pm 0.000015 & \pm 0.000018 & \pm 0.000017 \\
\hline${ }^{143} \mathrm{Nd} /{ }^{144} \mathrm{Nd}_{58}$ & 0.512867 & 0.512815 & 0.512854 & 0.512723 & 0.512947 & 0.512639 & 0.513013 & 0.512840 \\
\hline $2 \mathrm{se}$ & \pm 0.000035 & \pm 0.000007 & \pm 0.000009 & \pm 0.000013 & \pm 0.000008 & \pm 0.000009 & \pm 0.000011 & \pm 0.000006 \\
\hline$\varepsilon \mathrm{Nd}_{58}$ & 5.8 & 4.8 & 5.6 & 3.0 & 9.3 & 1.4 & 8.7 & 5.3 \\
\hline${ }^{206} \mathrm{~Pb} /{ }^{204} \mathrm{~Pb}$ & 17.859 & 17.361 & 17.290 & 17.271 & 17.712 & 17.017 & & \\
\hline $2 \mathrm{se}$ & \pm 0.015 & \pm 0.006 & \pm 0.008 & \pm 0.008 & \pm 0.008 & \pm 0.008 & & \\
\hline${ }^{207} \mathrm{~Pb} /{ }^{204} \mathrm{~Pb}$ & 15.474 & 15.426 & 15.406 & 15.398 & 15.404 & 15.353 & & \\
\hline $2 \mathrm{se}$ & \pm 0.009 & \pm 0.007 & \pm 0.007 & \pm 0.008 & \pm 0.008 & \pm 0.00 & & \\
\hline${ }^{208} \mathrm{~Pb} /{ }^{204} \mathrm{~Pb}$ & 37.634 & 37.006 & 36.923 & 37.114 & 37.471 & 36.459 & & \\
\hline $2 \mathrm{se}$ & \pm 0.016 & \pm 0.013 & \pm 0.019 & \pm 0.008 & \pm 0.019 & \pm 0.017 & & \\
\hline$\delta^{18} \mathrm{O} \%$ & & & & & 5.9 & 6.4 & & \\
\hline
\end{tabular}


Table 1 cont.

\begin{tabular}{|c|c|c|c|c|c|c|c|c|}
\hline Sample \# & MHI14.4 & GIG5.5 & MHJ2.10 & MHI2.2 & MHI5.3 & MHI8.8 & MHJ2.13 & GIG3.1 \\
\hline $\mathrm{SiO}_{2}$ & 46.68 & 47.60 & 47.52 & 47.05 & 46.78 & 46.64 & 46.62 & 45.1 \\
\hline $\mathrm{TiO}_{2}$ & 1.32 & 1.36 & 1.27 & 1.20 & 1.10 & 1.53 & 0.82 & 1.49 \\
\hline $\mathrm{Al}_{2} \mathrm{O}_{3}$ & 16.11 & 18.16 & 15.26 & 17.26 & 15.67 & 16.19 & 13.43 & 16.13 \\
\hline $\mathrm{Fe}_{2} \mathrm{O}_{3 \mathrm{~T}}$ & 12.23 & 13.38 & 12.57 & 13.14 & 12.56 & 15.25 & 11.86 & 14.21 \\
\hline $\mathrm{MnO}$ & 0.18 & 0.22 & 0.17 & 0.16 & 0.18 & 0.23 & 0.18 & 0.18 \\
\hline $\mathrm{MgO}$ & 9.93 & 7.43 & 10.36 & 8.79 & 11.04 & 6.27 & 16.16 & 8.86 \\
\hline $\mathrm{CaO}$ & 8.56 & 8.01 & 10.59 & 10.5 & 9.90 & 8.40 & 8.65 & 9.85 \\
\hline $\mathrm{Na}_{2} \mathrm{O}$ & 2.92 & 2.58 & 2.09 & 2.27 & 2.54 & 4.63 & 1.74 & 3.29 \\
\hline $\mathrm{K}_{2} \mathrm{O}$ & 0.30 & 0.14 & 0.28 & 0.16 & 0.31 & 0.12 & 0.12 & 0.10 \\
\hline $\mathrm{P}_{2} \mathrm{O}_{5}$ & 0.14 & 0.18 & 0.15 & 0.18 & 0.15 & 0.13 & 0.31 & 0.13 \\
\hline Total & 98.37 & 99.07 & 100.27 & 100.71 & 100.24 & 99.22 & 99.89 & 99.34 \\
\hline LOI & 1.57 & 4.59 & 2.31 & 1.82 & 1.87 & 1.94 & 3.73 & 0.45 \\
\hline \multicolumn{9}{|c|}{ Trace elements in ppm } \\
\hline $\mathrm{Cr}$ & 602.3 & 27 & 578 & 36 & 467 & 22 & 1544 & 83 \\
\hline $\mathrm{Ni}$ & 387.3 & 52 & 336 & 123 & 290 & 72 & 502 & 195 \\
\hline Co & 60.9 & 51.9 & 59.8 & 56.4 & 59.9 & 47.8 & 69.2 & 62.3 \\
\hline Cs & 0.29 & 0.89 & 0.62 & & 0.56 & 0.75 & & \\
\hline $\mathrm{Rb}$ & 4.45 & 2 & 3.23 & 2 & 4 & 2 & 3.25 & 2.12 \\
\hline $\mathrm{Sr}$ & 336.8 & 429 & 289 & 186 & 233 & 378 & 174 & 305 \\
\hline $\mathrm{Ba}$ & 166.4 & 140 & 66.5 & 79 & 69 & 226 & 2036.2 & 33.4 \\
\hline $\mathrm{Hf}$ & 2.32 & 2.49 & 2.12 & 1.97 & 2.1 & 3.21 & 1.63 & 2.42 \\
\hline $\mathrm{Zr}$ & 82.4 & 109 & 76.6 & 78.8 & 90 & 127 & 59.9 & 88 \\
\hline $\mathrm{Nb}$ & 1.5 & 2.4 & 1.4 & 1.3 & 2.1 & 3.1 & 1.2 & 2.2 \\
\hline Тa & 0.09 & 0.12 & 0.08 & 0.11 & 0.14 & 0.28 & 0.09 & 0.14 \\
\hline $\mathrm{Y}$ & 22.3 & 24.6 & 23 & 26.9 & 22 & 30.5 & 18 & 23 \\
\hline $\mathrm{Sc}$ & 35.4 & 31.1 & 36.1 & & 33.8 & & 33 & 35.1 \\
\hline $\mathrm{Pb}$ & 4.12 & & 1.01 & & & & 0.94 & 0.74 \\
\hline $\mathrm{U}$ & 0.05 & & 0.07 & & & & 0.07 & 0.05 \\
\hline Th & 0.13 & 0.3 & 0.27 & 0.3 & 0.65 & 0.46 & 0.27 & 0.16 \\
\hline $\mathrm{La}$ & 4.61 & 6.6 & 3.33 & 2.9 & 4.2 & 5.1 & 3.51 & 2.95 \\
\hline $\mathrm{Ce}$ & 12.1 & 15.7 & 9.03 & 7.4 & 10.3 & 14 & 8.47 & 8.61 \\
\hline $\operatorname{Pr}$ & 2.05 & & 1.56 & & & & 1.41 & 1.59 \\
\hline $\mathrm{Nd}$ & 11.09 & 12.9 & 8.49 & 7.1 & 9 & 12.3 & 7.69 & 8.66 \\
\hline $\mathrm{Sm}$ & 3.28 & 3.83 & 2.92 & 2.74 & 2.82 & 4 & 2.52 & 3.15 \\
\hline $\mathrm{Eu}$ & 1.25 & 1.39 & 1.13 & 1.11 & 1.1 & 1.61 & 1.13 & 1.22 \\
\hline Gd & 3.94 & & 3.71 & & & & 3.21 & 3.88 \\
\hline $\mathrm{Tb}$ & 0.7 & 0.77 & 0.67 & 0.73 & 0.58 & 0.92 & 0.55 & 0.68 \\
\hline Dy & 4.25 & & 4.27 & & & & 3.64 & 4.25 \\
\hline Но & 0.89 & & 0.91 & & & & 0.77 & 0.88 \\
\hline Er & 2.33 & & 2.44 & & & & 2.15 & 2.37 \\
\hline Tm & 0.34 & & 0.37 & & & & 0.32 & 0.34 \\
\hline $\mathrm{Yb}$ & 2.03 & 2.57 & 2.17 & 2.76 & 2.11 & 3.11 & 1.99 & 2.04 \\
\hline $\mathrm{Lu}$ & 0.31 & 0.39 & 0.35 & 0.43 & 0.34 & 0.48 & 0.3 & 0.3 \\
\hline${ }^{87} \mathrm{Sr} /{ }^{86} \mathrm{Sr}_{58}$ & 0.704129 & 0.704450 & 0.704314 & 0.703968 & 0.704826 & 0.703234 & 0.704308 & 0.703375 \\
\hline $2 \mathrm{se}$ & \pm 0.000020 & \pm 0.000015 & \pm 0.000023 & \pm 0.000018 & \pm 0.000016 & \pm 0.000014 & \pm 0.000018 & \pm 0.000018 \\
\hline${ }^{143} \mathrm{Nd} /{ }^{144} \mathrm{Nd}_{58}$ & 0.512555 & 0.512408 & 0.512703 & 0.512828 & 0.512700 & 0.5129601 & 0.512566 & 0.513009 \\
\hline $2 \mathrm{se}$ & \pm 0.000012 & \pm 0.000013 & \pm 0.000010 & \pm 0.000008 & \pm 0.000006 & \pm 0.000011 & \pm 0.000012 & \pm 0.000010 \\
\hline$\varepsilon \mathrm{Nd}_{58}$ & -0.2 & -3.1 & 2.6 & 5.8 & 2.6 & 7.7 & 0.0 & 8.6 \\
\hline${ }^{206} \mathrm{~Pb} /{ }^{204} \mathrm{~Pb}$ & 16.723 & 16.612 & 17.739 & 17.853 & 18.389 & 18.157 & 17.180 & 17.703 \\
\hline $2 \mathrm{se}$ & \pm 0.006 & \pm 0.013 & \pm 0.007 & \pm 0.005 & \pm 0.005 & \pm 0.010 & \pm 0.011 & \pm 0.012 \\
\hline${ }^{207} \mathrm{~Pb} /{ }^{204} \mathrm{~Pb}$ & 15.341 & 15.262 & 15.455 & 15.478 & 15.548 & 15.463 & 15.426 & 15.424 \\
\hline $2 \mathrm{se}$ & \pm 0.006 & \pm 0.017 & \pm 0.008 & \pm 0.005 & \pm 0.006 & \pm 0.009 & \pm 0.020 & \pm 0.013 \\
\hline${ }^{208} \mathrm{~Pb} /{ }^{204} \mathrm{~Pb}$ & 36.324 & 36.223 & 37.586 & 37.622 & 38.170 & 37.862 & 37.006 & 37.543 \\
\hline $2 \mathrm{se}$ & \pm 0.016 & \pm 0.034 & \pm 0.026 & \pm 0.013 & \pm 0.013 & \pm 0.017 & \pm 0.036 & \pm 0.006 \\
\hline$\delta^{18} \mathrm{O} \%$ & 5.8 & 6.0 & 5.7 & & & 6.1 & & 5.8 \\
\hline
\end{tabular}


Table 1 cont.

\begin{tabular}{|c|c|c|c|c|c|c|c|c|}
\hline Sample \# & MHI6.2 & MHJ3.3 & MHI6.3 & MHJ3.9 & MHI 2.11 & MHI4.1 & MHI4.10 & MHI2.10 \\
\hline $\mathrm{SiO}_{2}$ & 46.02 & 46.58 & 47.94 & 46.95 & 45.77 & 47.77 & 47.66 & 47.71 \\
\hline $\mathrm{TiO}_{2}$ & 1.07 & 1.29 & 0.97 & 0.98 & 0.89 & 1.10 & 0.92 & 0.80 \\
\hline $\mathrm{Al}_{2} \mathrm{O}_{3}$ & 15.08 & 14.83 & 16.47 & 16.47 & 16.77 & 18.59 & 18.58 & 16.08 \\
\hline $\mathrm{Fe}_{2} \mathrm{O}_{3 \mathrm{~T}}$ & 12.25 & 11.23 & 10.69 & 11.37 & 12.33 & 12.39 & 11.46 & 11.29 \\
\hline $\mathrm{MnO}$ & 0.17 & 0.06 & 0.17 & 0.16 & 0.18 & 0.19 & 0.18 & 0.17 \\
\hline $\mathrm{MgO}$ & 11.43 & 13.65 & 8.08 & 11.31 & 12.01 & 7.48 & 10.19 & 10.92 \\
\hline $\mathrm{CaO}$ & 9.45 & 9.09 & 12.05 & 11.19 & 8.24 & 9.29 & 9.11 & 11.68 \\
\hline $\mathrm{Na}_{2} \mathrm{O}$ & 2.72 & 2.51 & 1.65 & 1.49 & 2.41 & 2.59 & 2.63 & 1.86 \\
\hline $\mathrm{K}_{2} \mathrm{O}$ & 0.09 & 0.36 & 0.23 & 0.31 & 0.34 & 0.03 & 0.02 & 0.07 \\
\hline $\mathrm{P}_{2} \mathrm{O}_{5}$ & 0.10 & 0.16 & 0.07 & 0.12 & 0.11 & 0.09 & 0.09 & 0.12 \\
\hline Total & 98.38 & 99.76 & 98.33 & 100.35 & 99.05 & 99.53 & 100.82 & 100.72 \\
\hline LOI & 0.73 & 2.71 & 4.63 & 2.58 & 1.42 & 1.30 & 0.90 & 2.00 \\
\hline \multicolumn{9}{|c|}{ Trace elements in ppm } \\
\hline $\mathrm{Cr}$ & 424 & 799.3 & 295 & 270 & 433 & 49 & 320 & 566 \\
\hline $\mathrm{Ni}$ & 318 & 457.2 & 152 & 290 & 317 & 158 & 272 & 287 \\
\hline Co & 66.8 & 64.6 & 44.7 & 54.2 & 56.8 & 53.3 & 55.9 & 56.5 \\
\hline Cs & 0.43 & 0.54 & 0.37 & 0.75 & & & & \\
\hline $\mathrm{Rb}$ & 3.07 & 2.98 & 2 & 4.76 & 1.39 & 2 & 2 & 1.87 \\
\hline $\mathrm{Sr}$ & 238 & 235.5 & 170 & 226 & 131 & 182 & 293 & 108 \\
\hline $\mathrm{Ba}$ & 51.5 & 176.7 & 58 & 169 & 126.1 & 20 & & 36.5 \\
\hline Hf & 1.96 & 1.84 & 1.77 & 1.57 & 1.66 & 1.8 & 1.47 & 1.16 \\
\hline $\mathrm{Zr}$ & 71.2 & 69.7 & 74 & 56 & 62.9 & 66 & 48 & 38.6 \\
\hline $\mathrm{Nb}$ & 1.7 & 1.6 & 2 & 1.4 & 2 & 2 & 1.6 & 1.1 \\
\hline $\mathrm{Ta}$ & 0.11 & 0.09 & 0.12 & 0.08 & 0.11 & 0.1 & 0.09 & 0.06 \\
\hline $\mathrm{Y}$ & 21 & 24.5 & 26.5 & 22 & 22.5 & 26 & 17.9 & 20.9 \\
\hline $\mathrm{Sc}$ & 34 & 30.7 & 44.9 & 37.4 & 30.9 & 32.8 & 28.2 & 41 \\
\hline $\mathrm{Pb}$ & 0.92 & 1.05 & & 1.27 & 0.54 & & & 0.53 \\
\hline $\mathrm{U}$ & 0.09 & 0.05 & & 0.04 & 0.04 & & & 0.09 \\
\hline Th & 0.31 & 0.14 & 0.91 & 0.16 & 0.13 & & 0.2 & 0.17 \\
\hline $\mathrm{La}$ & 3.27 & 4.3 & 5.4 & 4 & 3.01 & 2.9 & 2.7 & 1.94 \\
\hline $\mathrm{Ce}$ & 8.88 & 10.68 & 10.4 & 9.5 & 7.91 & 6.8 & 6.7 & 4.85 \\
\hline $\operatorname{Pr}$ & 1.52 & 1.78 & & 1.5 & 1.32 & & & 0.8 \\
\hline $\mathrm{Nd}$ & 8.27 & 9.64 & 8.1 & 8.18 & 7.23 & 7.4 & 6.2 & 4.5 \\
\hline $\mathrm{Sm}$ & 2.59 & 2.81 & 2.69 & 2.5 & 2.51 & 2.68 & 2.16 & 1.73 \\
\hline $\mathrm{Eu}$ & 1.01 & 1.04 & 1.02 & 1.03 & 1 & 1.1 & 0.9 & 0.69 \\
\hline Gd & 3.18 & 3.28 & & 3.27 & 3.23 & & & 2.44 \\
\hline $\mathrm{Tb}$ & 0.57 & 0.53 & 0.69 & 0.62 & 0.6 & 0.72 & 0.53 & 0.48 \\
\hline Dy & 3.52 & 3.21 & & 3.9 & 3.93 & & & 3.17 \\
\hline Ho & 0.75 & 0.63 & & 0.87 & 0.83 & & & 0.69 \\
\hline Er & 2.02 & 1.71 & & 2.38 & 2.33 & & & 1.99 \\
\hline $\mathrm{Tm}$ & 0.31 & 0.25 & & 0.37 & 0.35 & & & 0.31 \\
\hline $\mathrm{Yb}$ & 1.93 & 1.53 & 2.64 & 2.24 & 2.23 & 2.68 & 2 & 1.86 \\
\hline $\mathrm{Lu}$ & 0.28 & 0.22 & 0.43 & 0.36 & 0.34 & 0.44 & 0.31 & 0.31 \\
\hline${ }^{87} \mathrm{Sr} /{ }^{86} \mathrm{Sr}_{58}$ & 0.704207 & 0.703834 & & 0.704260 & 0.703440 & 0.703440 & & 0.704504 \\
\hline $2 \mathrm{se}$ & \pm 0.000014 & \pm 0.000018 & & \pm 0.000017 & \pm 0.000015 & \pm 0.000017 & & \pm 0.000017 \\
\hline${ }^{143} \mathrm{Nd} /{ }^{144} \mathrm{Nd}_{58}$ & & 0.512532 & & 0.512485 & 0.512798 & 0.512962 & & 0.512707 \\
\hline $2 \mathrm{se}$ & & \pm 0.000010 & & \pm 0.000010 & \pm 0.000014 & \pm 0.000011 & & \pm 0.000010 \\
\hline$\varepsilon \mathrm{Nd}_{58}$ & & -0.5 & & -1.6 & 4.5 & 7.7 & & 2.7 \\
\hline${ }^{206} \mathrm{~Pb} /{ }^{204} \mathrm{~Pb}$ & 18.206 & 16.773 & & 16.634 & 17.257 & 18.195 & & 18.313 \\
\hline $2 \mathrm{se}$ & \pm 0.012 & \pm 0.005 & & \pm 0.007 & \pm 0.006 & \pm 0.008 & & \pm 0.010 \\
\hline${ }^{207} \mathrm{~Pb} /{ }^{204} \mathrm{~Pb}$ & 15.494 & 15.361 & & 15.332 & 15.412 & 15.491 & & 15.514 \\
\hline $2 \mathrm{se}$ & \pm 0.010 & \pm 0.005 & & \pm 0.008 & \pm 0.007 & \pm 0.008 & & \pm 0.020 \\
\hline${ }^{208} \mathrm{~Pb} /{ }^{204} \mathrm{~Pb}$ & 37.493 & 36.154 & & 16.154 & 36.864 & 37.998 & & 38.203 \\
\hline $2 \mathrm{se}$ & \pm 0.021 & \pm 0.017 & & \pm 0.017 & \pm 0.016 & \pm 0.019 & & \pm 0.031 \\
\hline$\delta^{18} \mathrm{O} \%$ & 5.8 & & & 5.8 & & 6.2 & & 6.0 \\
\hline
\end{tabular}




\begin{tabular}{|c|c|c|c|c|c|c|c|}
\hline Sample & Location & $\begin{array}{l}\text { Mg\# } \\
\text { liquid }\end{array}$ & $\begin{array}{c}\text { Olivine } \\
\text { Fo }\end{array}$ & $\begin{array}{c}\text { Beattie } \\
\mathrm{T}^{\circ} \mathrm{C} \text { at } 0.9 \\
\mathrm{GPa}\end{array}$ & $\begin{array}{c}\text { Putirka } \\
\mathrm{T}^{\circ} \mathrm{C} \text { at } 0.9 \\
\mathrm{GPa}\end{array}$ & $\begin{array}{c}\text { Putirka } \\
\mathrm{T}^{\circ} \mathrm{C} \text { at } 1.6 \\
\mathrm{GPa}\end{array}$ & $\begin{array}{c}\text { Putirka } \\
\mathrm{T}_{\mathrm{P}} 0.9 \mathrm{at} \\
\mathrm{GPa}\end{array}$ \\
\hline MHI9.7 & IJDS & 73.5 & 89.8 & 1398 & 1393 & 1415 & 1530 \\
\hline MHJ3.3 & IJDS & 70.6 & 87.2 & 1397 & 1385 & 1395 & 1522 \\
\hline MHI6.2 & IJDS & 64.9 & 84.6 & 1344 & 1338 & 1358 & 1475 \\
\hline MHI14.10 & IJDS & 63.8 & 85.0 & 1298 & 1312 & 1325 & 1449 \\
\hline MHI6.6 & IJDS & 58.9 & 83.6 & 1326 & 1326 & 1350 & 1463 \\
\hline ВCH-24 & MPLF & 69.6 & 88.5 & 1381 & 1372 & 1393 & 1509 \\
\hline ВCH-27 & MPLF & 69.5 & 87.1 & 1380 & 1375 & 1396 & 1512 \\
\hline BR-6 & MPLF & 69.5 & 86.7 & 1384 & 1379 & 1400 & 1516 \\
\hline BHL-15 & MPLF & 68.5 & 87.6 & 1361 & 1356 & 1385 & 1493 \\
\hline BM16 & MPLF & 67.6 & 86.7 & 1371 & 1363 & 1385 & 1500 \\
\hline ВCH-33 & MPLF & 66.8 & 86.8 & 1366 & 1356 & 1379 & 1493 \\
\hline BR-5 & MPLF & 65.9 & 85.4 & 1363 & 1356 & 1377 & 1493 \\
\hline BHL-34 & MPLF & 65.9 & 85.6 & 1352 & 1349 & 1379 & 1486 \\
\hline AM-7a & MPLF & 65.4 & 85.5 & 1380 & 1372 & 1372 & 1509 \\
\hline BCH-14 & MPLF & 65.2 & 85.2 & 1360 & 1365 & 1377 & 1502 \\
\hline BB-22 & MPLF & 64.5 & 85.6 & 1360 & 1351 & 1372 & 1488 \\
\hline BHI-18 & MPLF & 61.6 & 83.6 & 1327 & 1320 & 1341 & 1457 \\
\hline BM8 & MPLF & 64.5 & 87.8 & 1345 & 1329 & 1350 & 1466 \\
\hline $66018^{1}$ & SMLS & 61.8 & 84.3 & 1345 & 1332 & 1358 & 1495 \\
\hline $66018^{2}$ & SMLS & 61.8 & 83.3 & - & - & 1358 & \\
\hline 2384-11 & Siqueiros $\mathrm{FZ}^{3}$ & 69.4 & 88.2 & 1300 & 1296 & - & 1433 \\
\hline $125-25-020 / 006$ & Siqueiros $\mathrm{FZ}^{3}$ & 68.9 & 89.7 & 1272 & 1268 & - & 1405 \\
\hline 2384-1 & Siqueiros $\mathrm{FZ}^{3}$ & 68.8 & 89.3 & 1265 & 1263 & - & 1400 \\
\hline
\end{tabular}

Table 2. Olivine-whole-rock equilibrium temperatures for BPIP basalts and Siquieros Fracture Zone ORB. IJDS, MPLF \& SMLS samples calculated at 0.9 and 1.6 GPa. Skye basalt \#66018 was the subject of highpressure melting experiments (Thompson 1974); ${ }^{1}$ Olivine phenocryst in natural lava; ${ }^{2}$ Olivine which crystallized at 10 kbar during melting experiment. ${ }^{3}$ Siqueiros FZ samples calculated at $0.8 \mathrm{GPa}$ (Perfit et al. 1996; Putirka et al. 2007). 


\begin{tabular}{|lrrrrrrr|}
\hline & MHI9.7 & MHI2.10 & \multicolumn{1}{c}{ MHI9.5 } & BM11-2 & BM29B & BHL26 & BHL21 \\
& IJDS & \multicolumn{1}{c}{ IJDS } & IJDS & MPLF & MPLF & MPLF & MPLF \\
\hline $\mathrm{SiO}_{2}$ & 47.57 & 46.72 & 46.91 & 46.13 & 45.90 & 45.99 & 45.84 \\
$\mathrm{TiO}_{2}$ & 0.92 & 0.69 & 0.85 & 0.62 & 0.70 & 0.70 & 0.88 \\
$\mathrm{Al}_{2} \mathrm{O}_{3}$ & 12.80 & 13.68 & 15.33 & 12.84 & 13.05 & 13.06 & 12.34 \\
$\mathrm{Fe}_{2} \mathrm{O}_{3}$ & 0.64 & 0.96 & 0.58 & 0.31 & 0.35 & 0.35 & 0.43 \\
$\mathrm{FeO}$ & 9.22 & 9.41 & 9.00 & 10.17 & 10.23 & 10.19 & 10.38 \\
$\mathrm{MnO}$ & 0.18 & 0.17 & 0.00 & 0.17 & 0.16 & 0.18 & 0.23 \\
$\mathrm{MgO}$ & 16.30 & 16.65 & 15.32 & 18.02 & 17.77 & 17.59 & 18.45 \\
$\mathrm{CaO}$ & 10.55 & 9.96 & 9.91 & 9.77 & 10.19 & 10.19 & 9.95 \\
$\mathrm{Na}_{2} \mathrm{O}$ & 1.66 & 1.58 & 1.98 & 1.20 & 1.50 & 1.65 & 1.39 \\
$\mathrm{~K}_{2} \mathrm{O}$ & 0.10 & 0.06 & 0.06 & 0.72 & 0.08 & 0.06 & 0.03 \\
$\mathrm{P}_{2} \mathrm{O}_{5}$ & 0.06 & 0.10 & 0.05 & 0.05 & 0.08 & 0.06 & 0.07 \\
$\mathrm{Fe}^{2+} / \Sigma$ Fe & 0.94 & 0.96 & 0.93 & 0.96 & 0.96 & 0.96 & 0.95 \\
$\%$ olivine & 2.5 & 16.7 & 19.8 & 26.7 & 24.5 & 21.4 & 25.9 \\
$k_{\mathrm{D}}$ & 0.318 & 0.315 & 0.314 & 0.310 & 0.310 & 0.310 & 0.310 \\
$\mathrm{Fo}$ & 90.8 & 90.9 & 90.6 & 91.4 & 90.9 & 90.8 & 91.1 \\
$\mathrm{~F}$ & 0.19 & 0.18 & 0.12 & 0.15 & 0.11 & 0.10 & 0.15 \\
$\mathbf{T}_{\mathbf{P}}{ }^{\circ}$ C [AFM] & $\mathbf{1 4 9 1}$ & $\mathbf{1 4 9 9}$ & $\mathbf{1 4 5 0}$ & $\mathbf{1 5 3 0}$ & $\mathbf{1 5 2 5}$ & $\mathbf{1 5 0 0}$ & $\mathbf{1 5 3 0}$ \\
$\mathrm{Residue}$ & $\mathrm{Harz}$ & $\mathrm{Sp} \mathrm{Lh}$ & $\mathrm{Sp} \mathrm{Lh}$ & Gt Lh & Gt Lh & Gt Lh & Gt Lh \\
\hline
\end{tabular}

Table 3. Results of the modelling of IJDS and MPLF (Kerr et al. 1999) mafic basalts. The $\mathrm{Fe}^{2+} / \Sigma \mathrm{Fe}$ is based on a constant $\mathrm{Fe}_{2} \mathrm{O}_{3} / \mathrm{TiO}_{2}$ ratio of 0.50 in the modelled composition (Herzberg \& Asimow 2008). However, $\mathrm{FeO}$ and $\mathrm{Fe}_{2} \mathrm{O}_{3}$ determinations on BPIP basalts with $\mathrm{Mg \#} \mathrm{c.} \mathrm{70,}$ suggest more oxidizing conditions may exists, giving a range of $\mathrm{Fe}^{2+} / \Sigma \mathrm{Fe}=0.94-0.96$ (Thompson 1974; Thompson et al. 1972). For the the $\mathrm{Fe}^{2+} / \Sigma \mathrm{Fe}$ ratios given the table, samples used in the models exhibit no evidence of augite fractionation or accumulation. Abbreviations; Harz, harzburgite residue; Sp Lh, spinel lherzolite residue; Gt Lh, garnet lherzolite residue. 

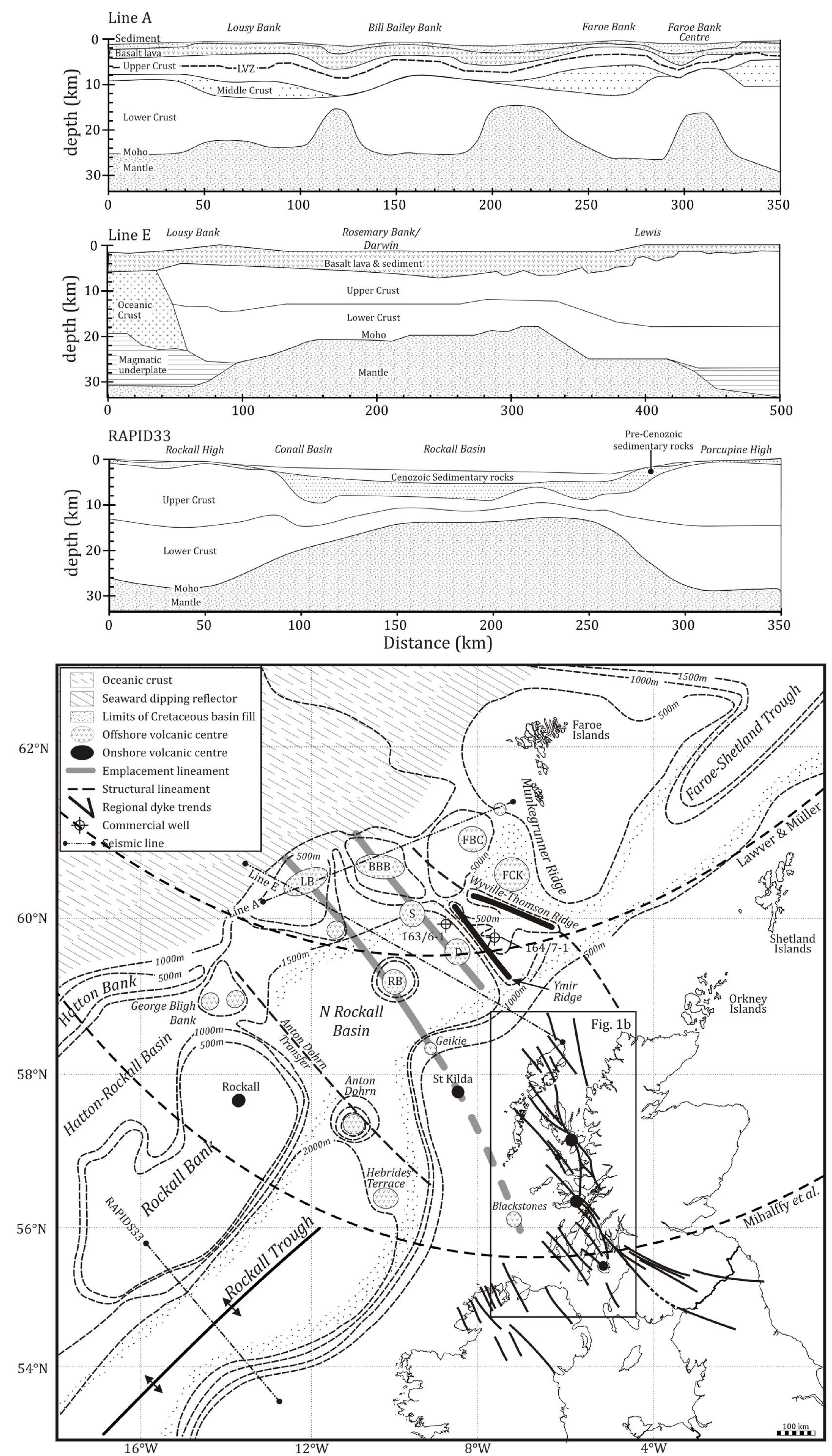


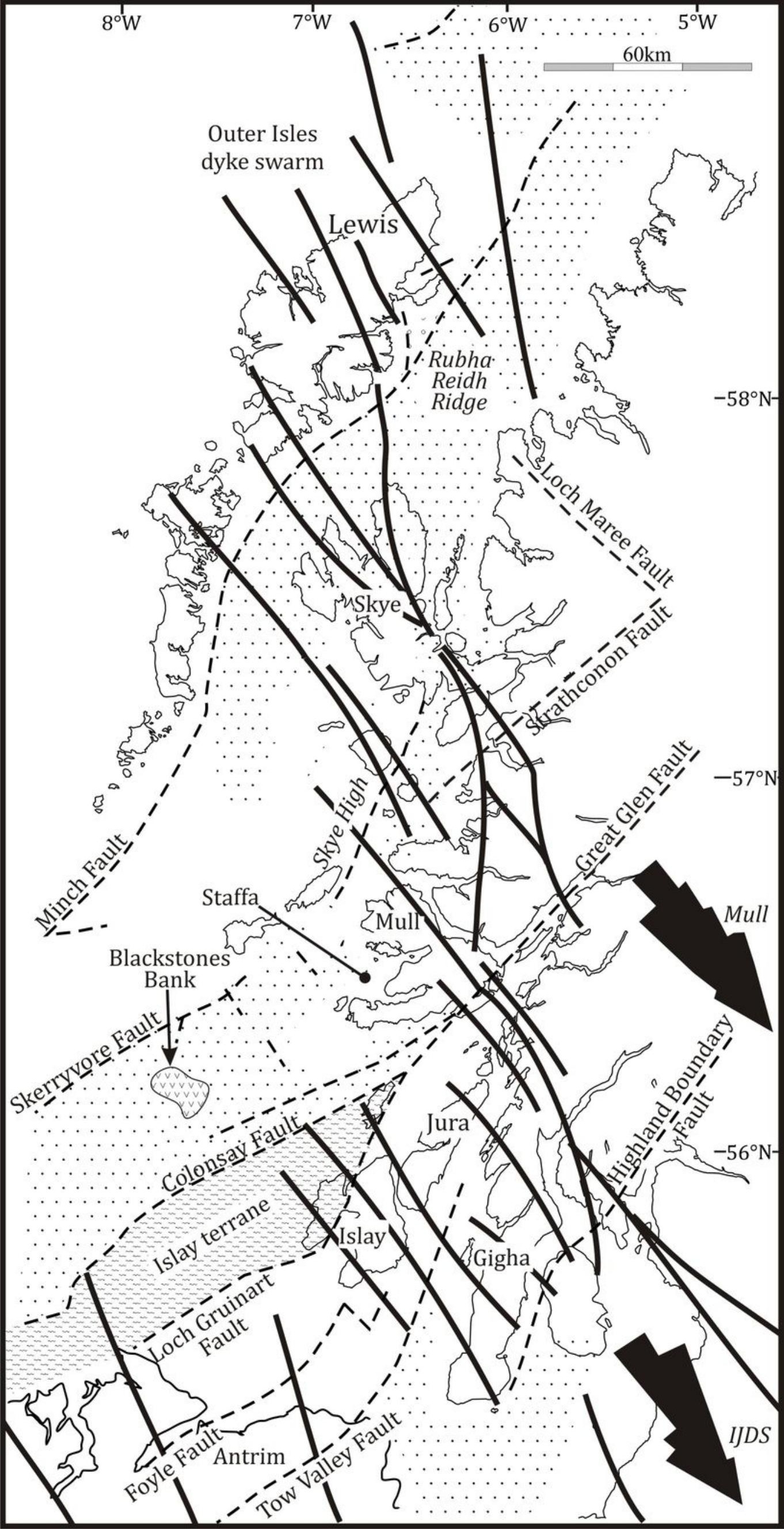




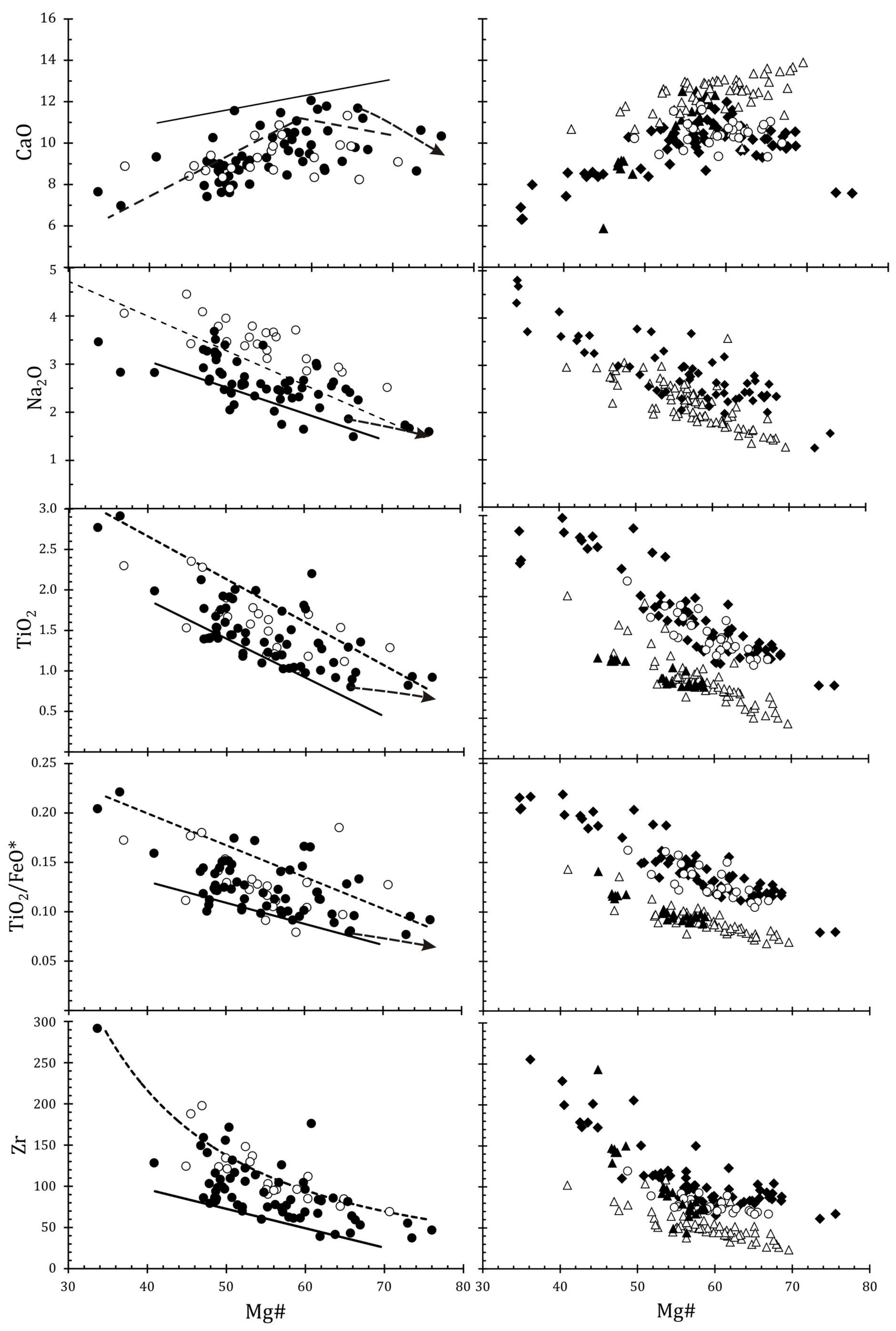




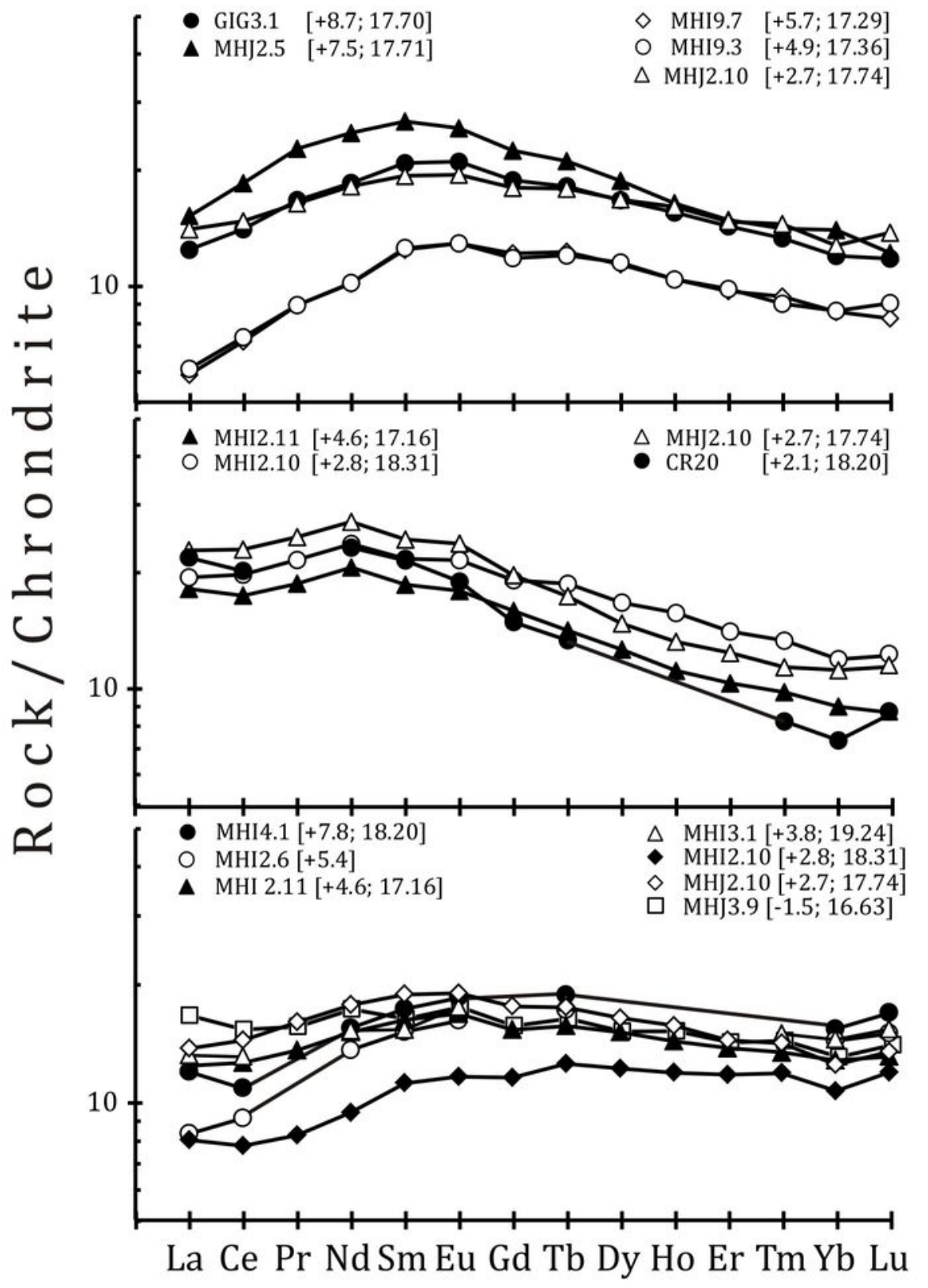




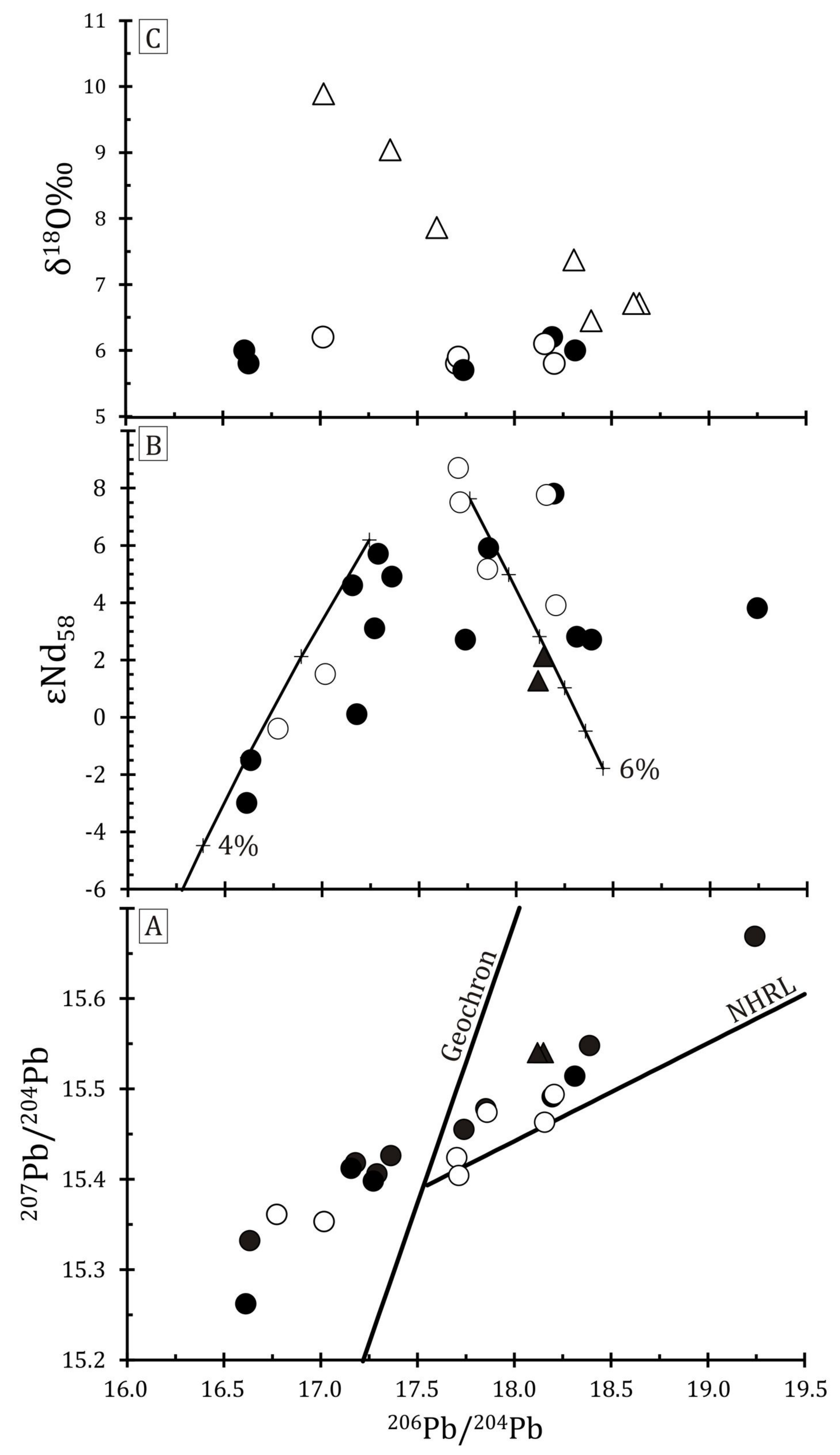




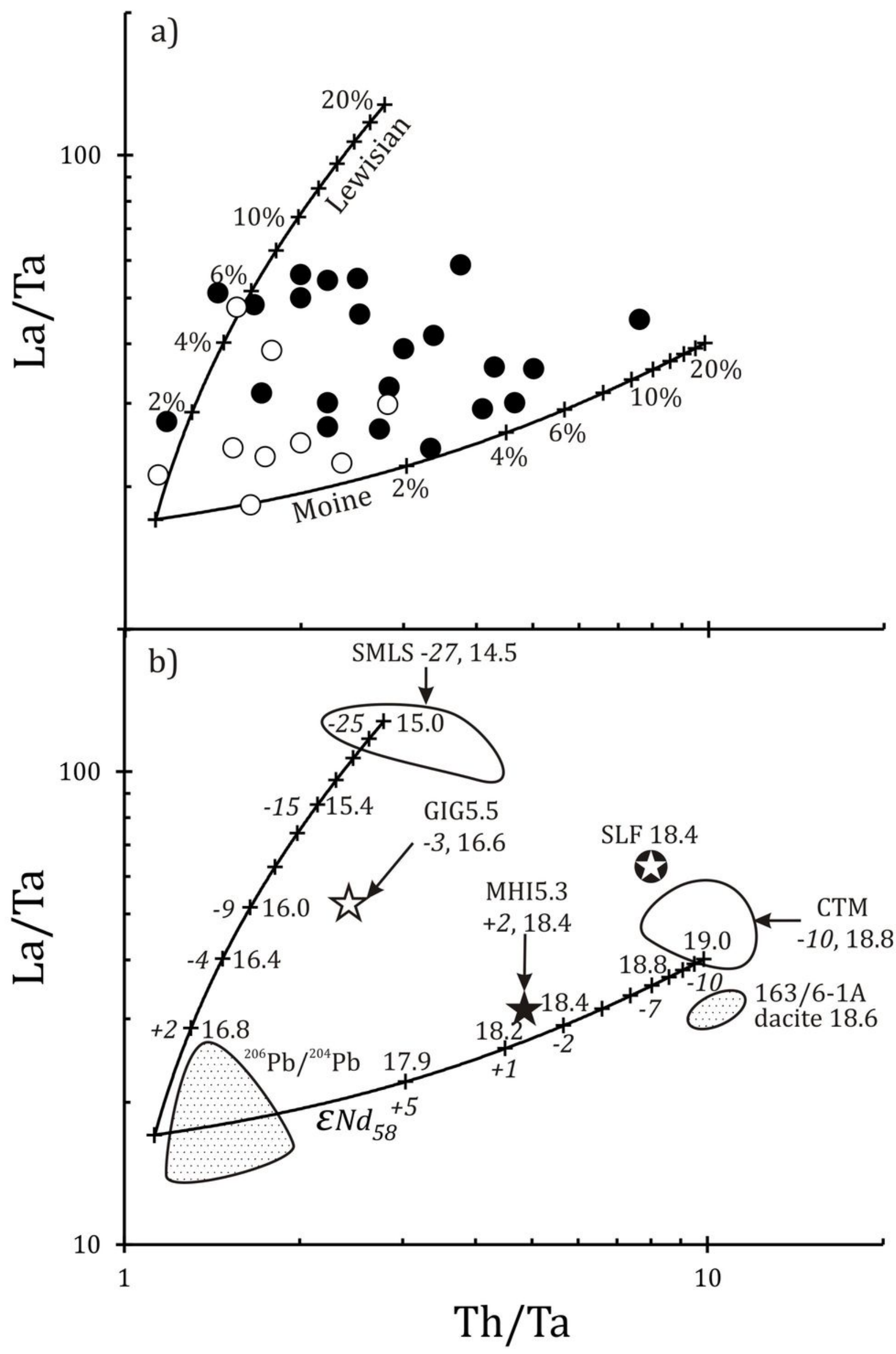




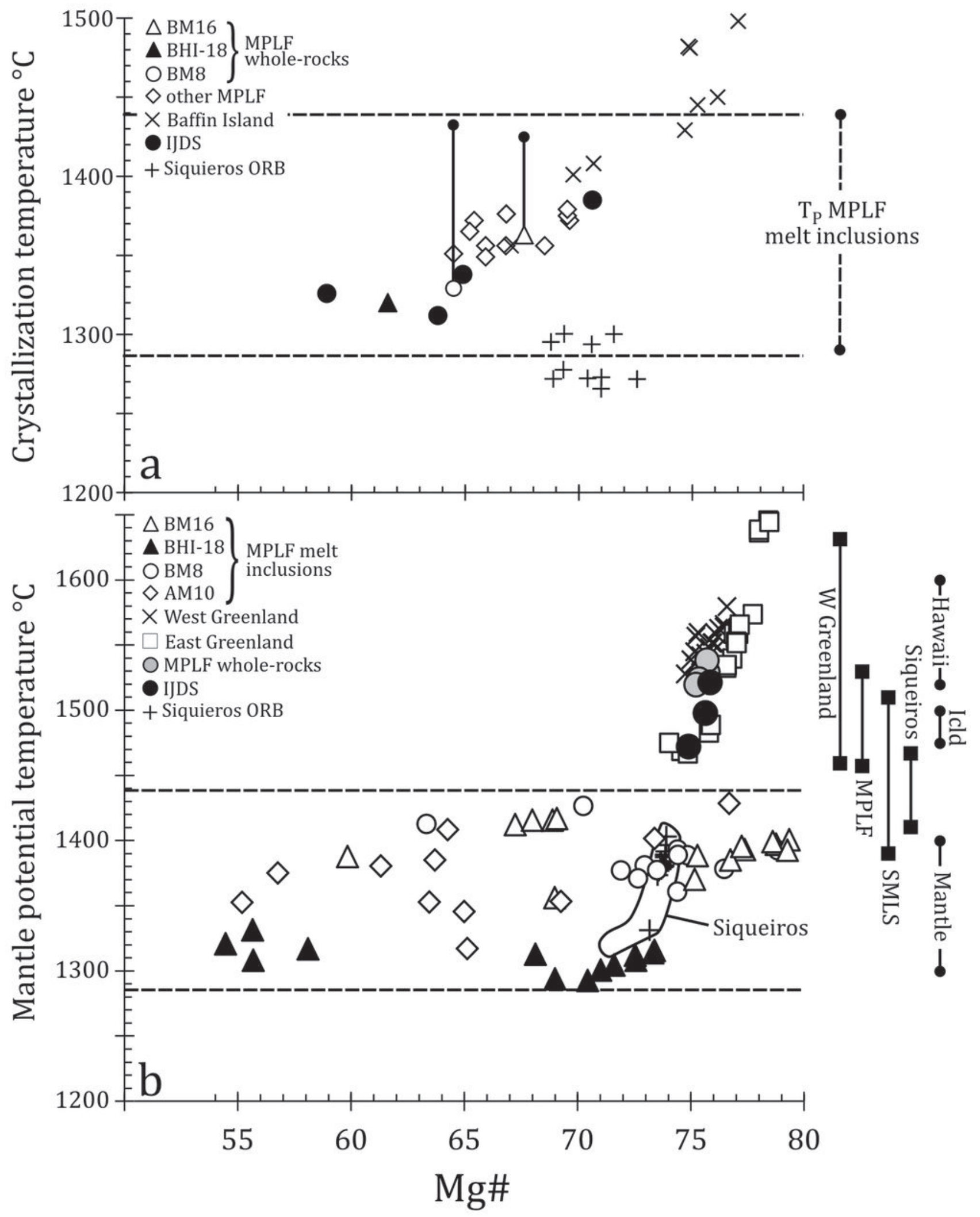




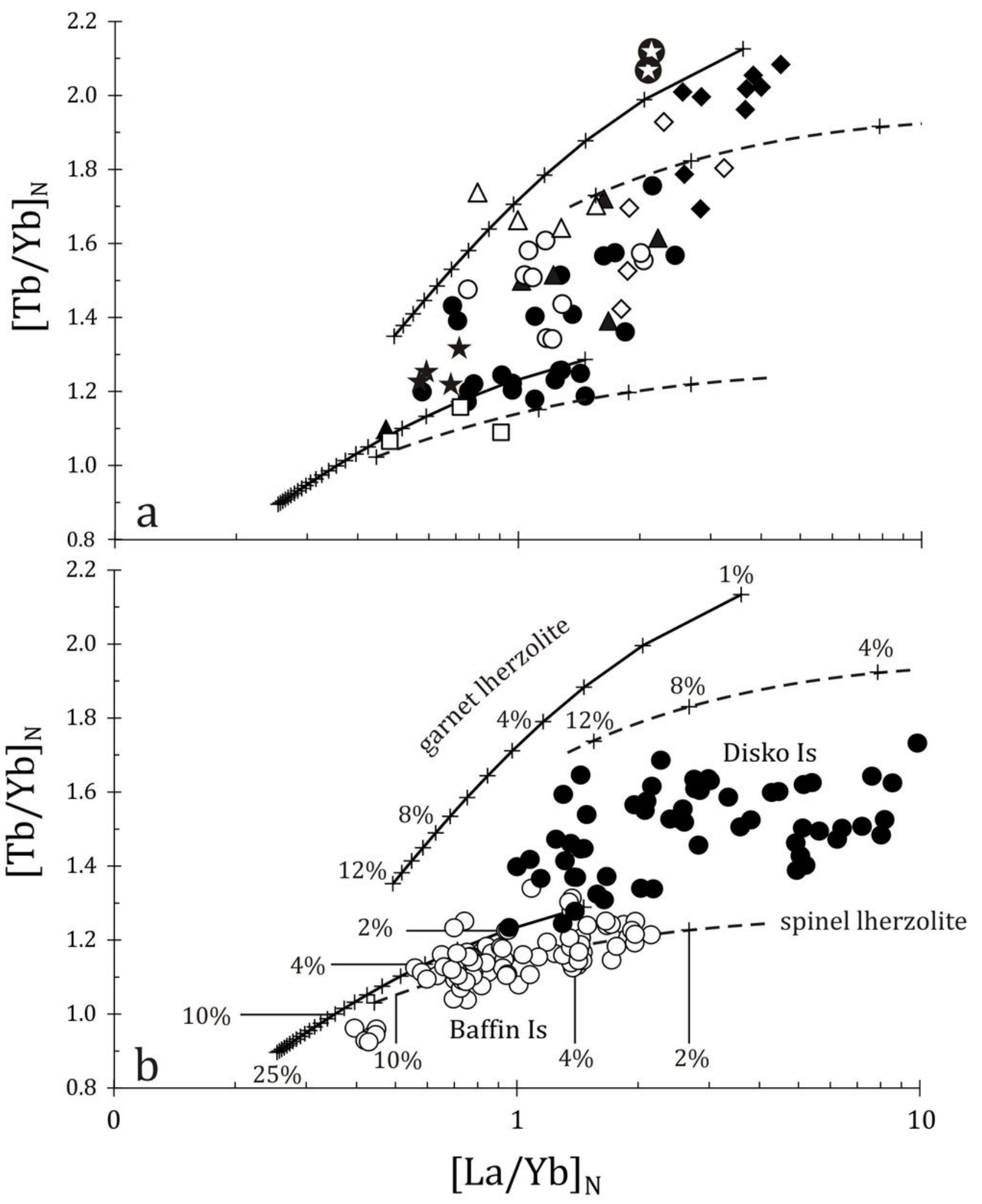


$\mathrm{T}^{\circ} \mathrm{C}$

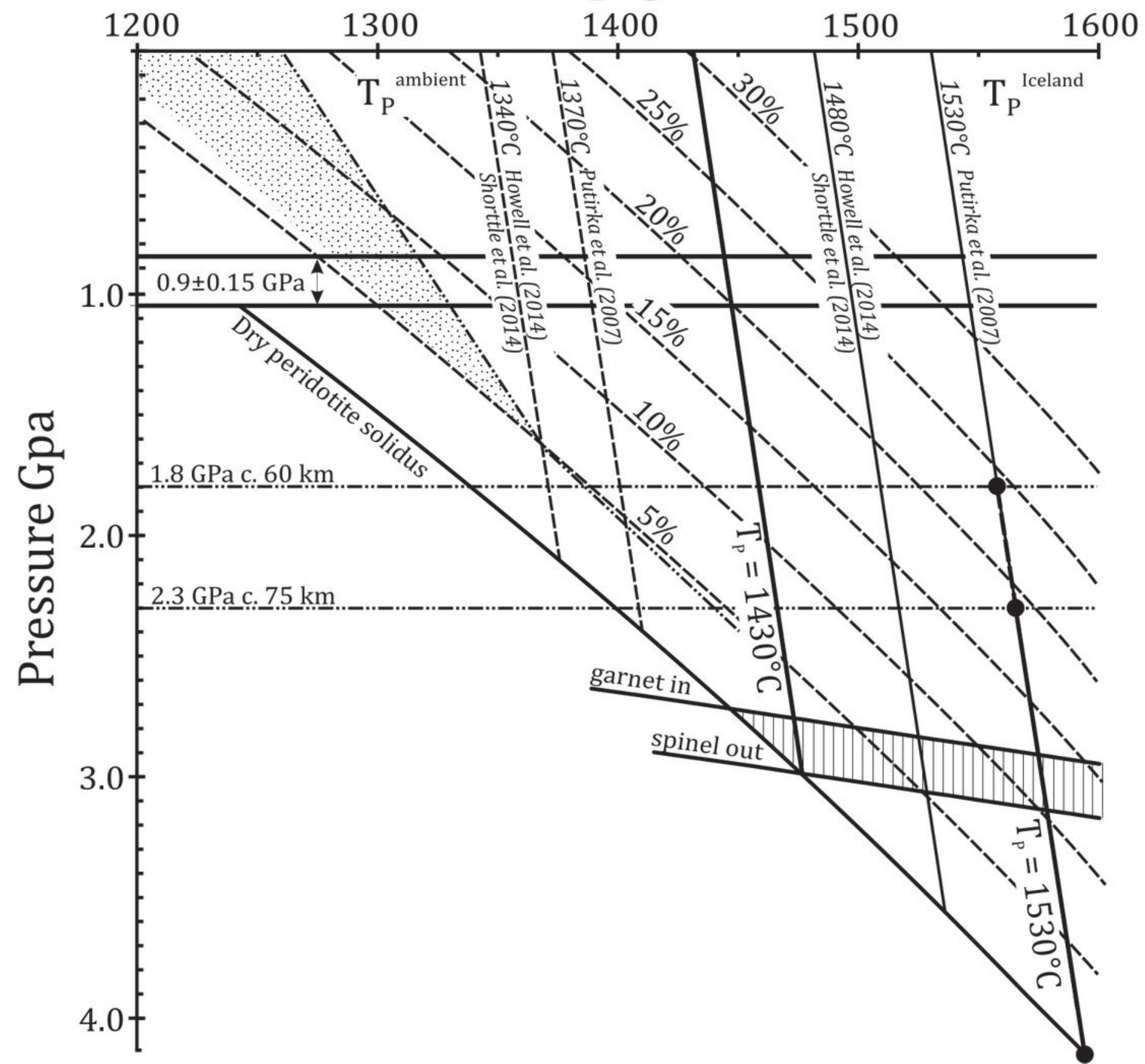




\section{Present-day}

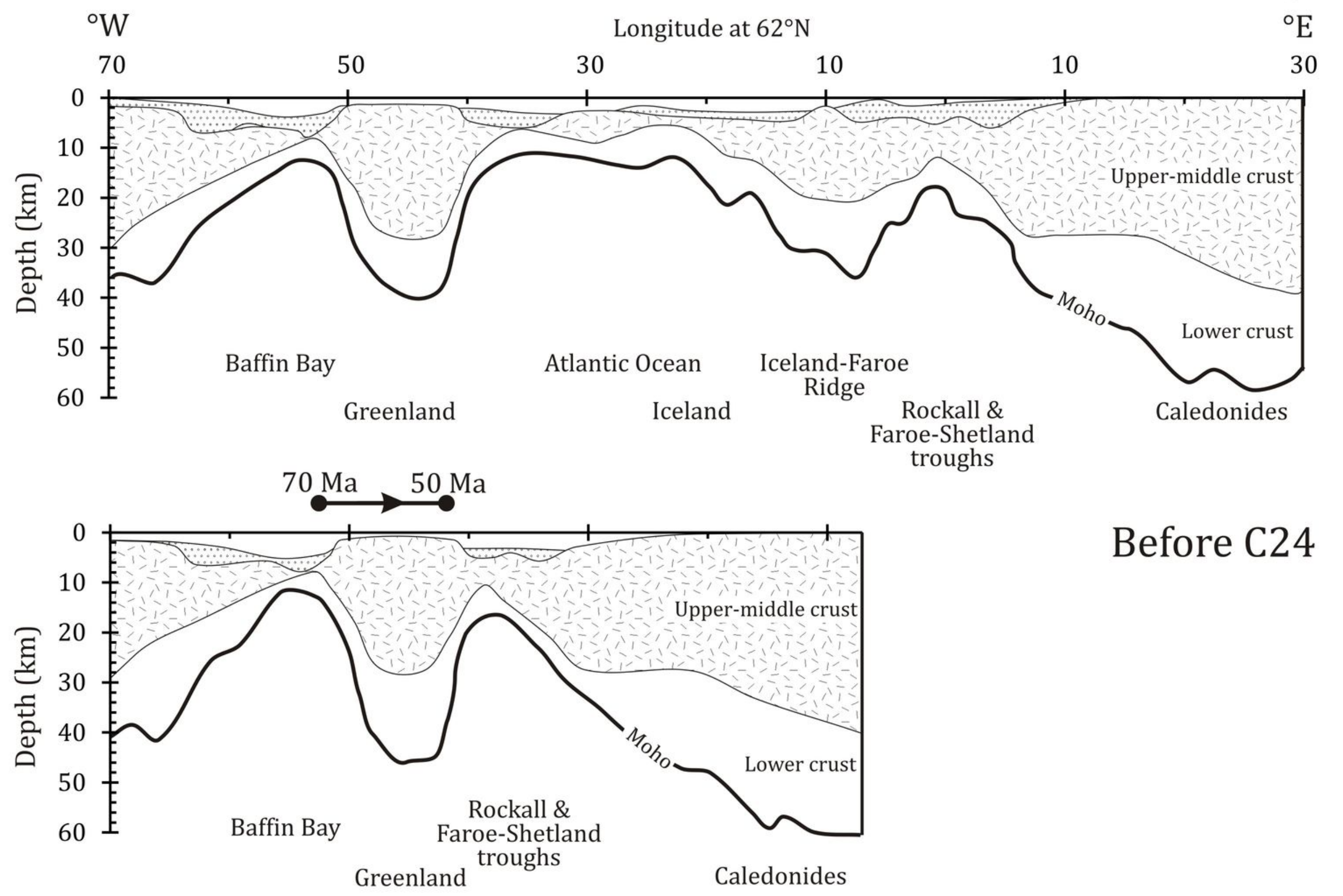

